University of Louisville

ThinkIR: The University of Louisville's Institutional Repository

Electronic Theses and Dissertations

$12-2010$

\title{
Passion for little people : personal paths for teaching elementary general music.
}

Rebecca Dennis 1983-

University of Louisville

Follow this and additional works at: https://ir.library.louisville.edu/etd

\section{Recommended Citation}

Dennis, Rebecca 1983-, "Passion for little people : personal paths for teaching elementary general music." (2010). Electronic Theses and Dissertations. Paper 334.

https://doi.org/10.18297/etd/334

This Master's Thesis is brought to you for free and open access by ThinkIR: The University of Louisville's Institutional Repository. It has been accepted for inclusion in Electronic Theses and Dissertations by an authorized administrator of ThinkIR: The University of Louisville's Institutional Repository. This title appears here courtesy of the author, who has retained all other copyrights. For more information, please contact thinkir@louisville.edu. 


\title{
PASSION FOR LITTLE PEOPLE:
}

\section{PERSONAL PATHS FOR TEACHING ELEMENTARY GENERAL MUSIC}

\author{
By \\ Rebecca Dennis \\ B.M.E., University of Louisville, 2005
}

\begin{abstract}
A Thesis
Submitted to the Faculty of the Graduate School of the University of Louisville In Partial Fulfillment of the Requirements for the Degree of
\end{abstract}

Master of Music Education

School of Music

University of Louisville

Louisville, KY

December 2010 



\title{
PASSION FOR LITTLE PEOPLE:
}

PERSONAL PATHS TO TEACH ELEMENTARY GENERAL MUSIC

\author{
By \\ Rebecca Dennis \\ B.M.E., University of Louisville, 2005
}

A Thesis Approved on

December 13, 2010

by the following Thesis Committee:

Thesis Director 


\section{DEDICATION}

This thesis is dedicated to my husband, Steven. He has supported and encouraged me throughout this project. I would also like to dedicate this thesis to my daughter, Leah.
Although her arrival made it more difficult to complete this project, she was also an inspiration. She was a constant reminder that I may better provide for my family by continuing to advance in my profession. 


\section{ACKNOWLEDGEMENTS}

I would like to thank my advisor, Dr. Robert A. Amchin, for his guidance and assistance throughout this project. I would also like to thank the other committee members, Dr. Barbara Wheeler and Dr. Amy Acklin for their comments and aid. I would also like to acknowledge Dr. Kate Fitzpatrick who first introduced me to research. I would also like to thank fellow colleagues and friends in the field for sharing their advice and lending an ear when support was needed.

I would like to acknowledge my former music teachers for inspiring my passion for music, Mr. Gary Parker, Mr. Barry Duvall, and Mr. Tony England. Regarding the focus of this study, I would like to acknowledge mentors and role models throughout my career who have provided positive experiences influencing my preference for elementary general music-Mrs. Alicia Franklin, Mr. Ken Downs, Mr. Brian Burnett, Mr. Brian

Crisp, Mrs. Cindy Hall, Mr. Jay Broeker, and, yet again, Dr. Robert A. Amchin. 


\begin{abstract}
PASSION FOR LITTLE PEOPLE:

PERSONAL PATHS FOR TEACHING ELEMENTARY GENERAL MUSIC
\end{abstract}

Rebecca I. Dennis

November 22,2010

This phenomenological study examines the experiences of current music teachers to determine what influences them to pursue a career teaching at the elementary level. Eight elementary music teachers from rural counties in Kentucky were interviewed during a two month period using open-response questions designed by the researcher. Participants recalled experiences from their childhood, collegiate career, and teaching career that influenced them prior to accepting positions in elementary general music. Results show that half of the participants decided to pursue elementary teaching during college and the other half decided they preferred elementary as a result of positive experiences while teaching in an elementary position. Nearly all the participants described negative experiences as a child in elementary music. All valued their field experience during college but wished they had more time in the classroom before entering the profession as elementary educators.

Most participants enjoyed the creative freedom in teaching elementary and enjoyed working with younger children and often mention the teaching approaches of Orff and Kodály. Many of the participants' most memorable experiences as teachers were 
of performances, noting that they enjoyed seeing students demonstrate what they have learned. The information gathered from this study resulted in recommendations for music education students, college professors teaching elementary music methods, and current elementary music teachers to pursue careers in elementary general music teaching. 
TABLE OF CONTENTS

PAGE

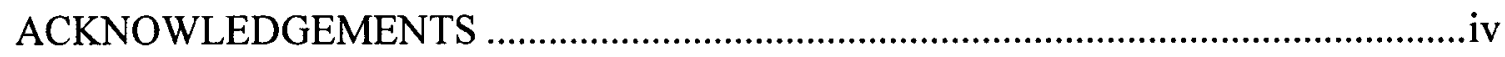

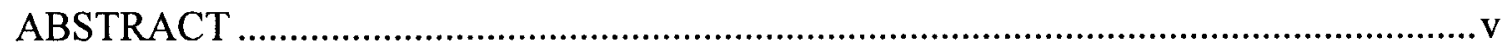

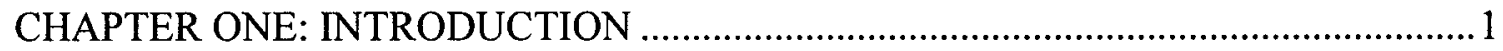

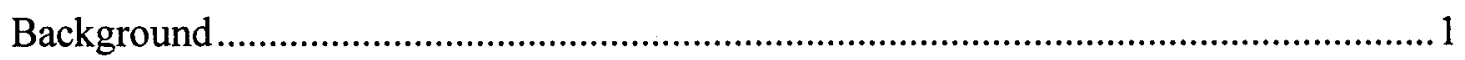

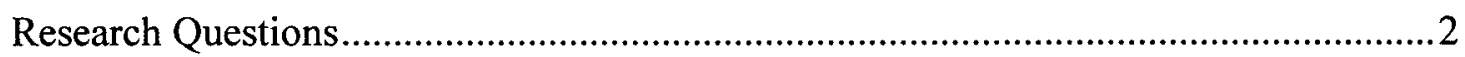

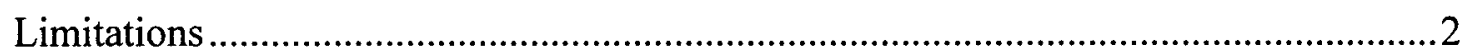

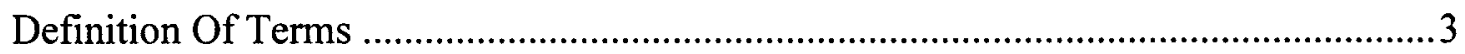

CHAPTER TWO: REVIEW OF LITERATURE ……................................................

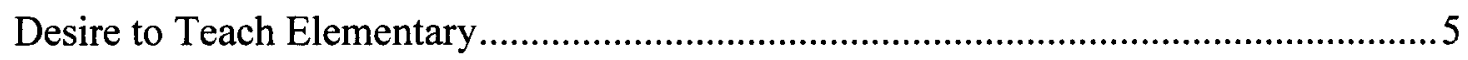

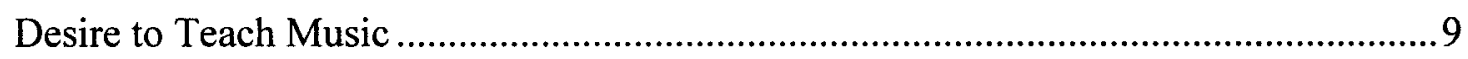

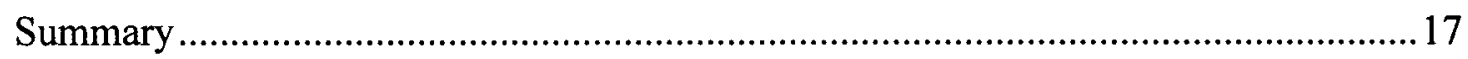

CHAPTER THREE: RESEARCH DESIGN AND METHODOLOGY ………...............19

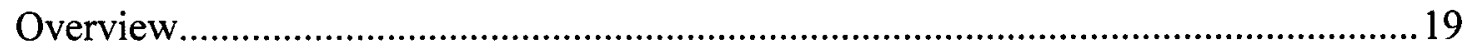

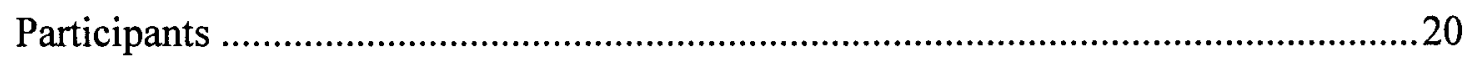

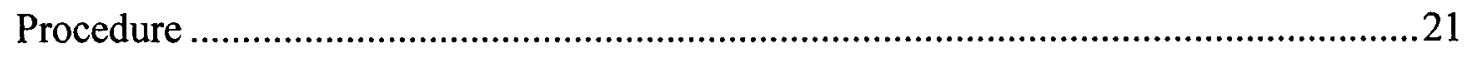

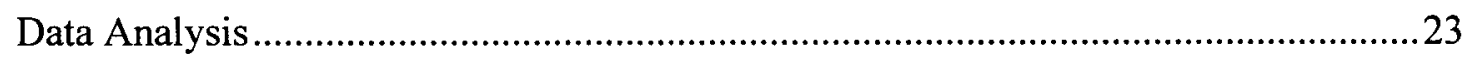

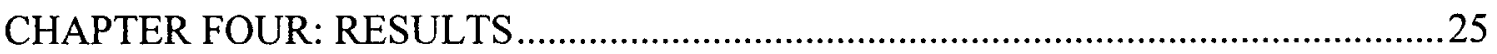

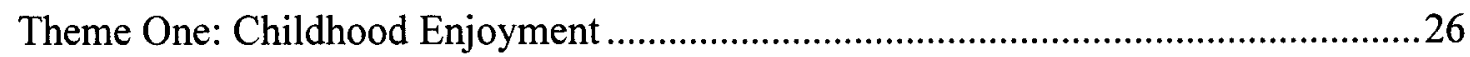

vii 
Theme Two: Pre-service Preference

Theme Three: Post-College Preference _.........................................................................

Theme Four: Value of Field Experience ....................................................................33

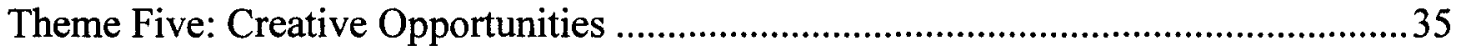

Theme Six: Interest in Young Learners.....................................................................37

Theme Seven: Value of Ensembles .......................................................................... 38

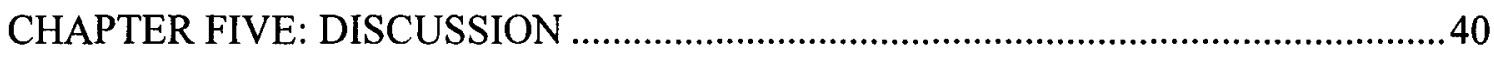

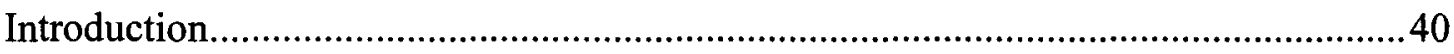

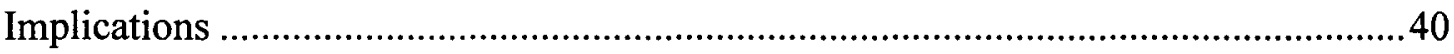

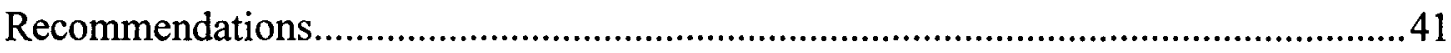

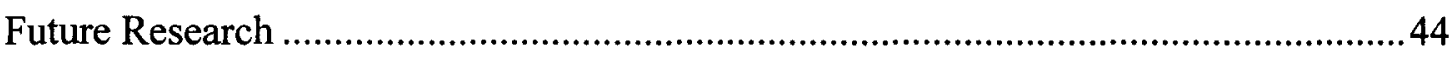

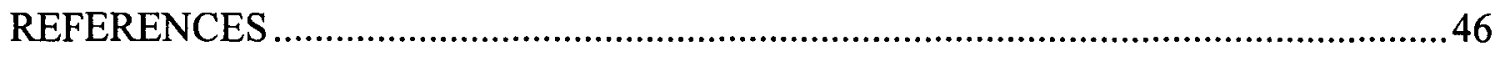

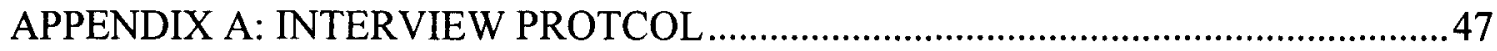

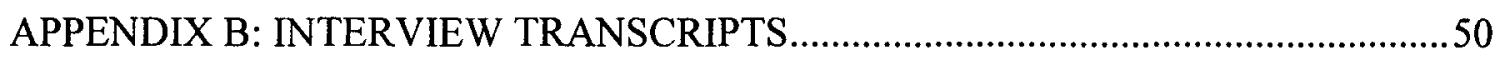

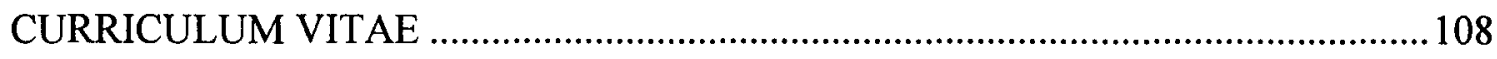




\section{CHAPTER ONE \\ INTRODUCTION}

\section{Background}

Research suggests that most music education majors enter college with the desire to become an ensemble director at the secondary level (Bertke, 2008; Gordon, 1999; Hellman, 2008). Many pursue this career path throughout their entire college career, while some develop a preference to teach music at the elementary level. When do these students decide to focus on elementary music? What specific experiences have influenced these music teachers to pursue teaching at the elementary level? If there are common experiences among many teachers, can this knowledge benefit the field of elementary music education and recruiting future music educators to consider teaching in this area?

Additionally, research has been done to explore the influence of elementary music methods courses in deciding a teaching preference (Campbell, 1999 \& Gordon, 1999). Results indicate that students often begin to prefer elementary teaching as a result of their methods course in college. However, other experiences outside of college may also influence their preference to teach elementary music. Other studies have explored elementary music teachers' identities as musicians and teachers, but provide little insight to why these pre-service teachers prefer to teach at the elementary level (Bernard, $2009 \&$ Wilcox 2003, 2004, 2005). It seems that an individual's entire life experiences should influence their career path. In order for a researcher to understand someone else's 
personal preference, it seems that experiences throughout the person's entire life ought be examined.

\section{RESEARCH QUESTIONS}

This study seeks to discover the following:

1) What experiences do current elementary music teachers describe from their childhood or collegiate career that have influenced their desire to teach at the elementary level?

2) What experiences do current elementary music teachers describe from their teaching careers that have influenced their decision to continue teaching at the elementary level?

3) How do these experiences affect a person's satisfaction as an elementary music teacher?

\section{LIMITATIONS}

The researcher in this project is also an elementary music teacher. The investigator tried to keep her personal bias from interfering with the study. All of the participants in this study taught at schools in a rural setting. The teachers' experiences could be different in an urban setting or different schools. All of the participants of this study were primarily self-described instrumentalists. While this was not intentional within the research design, no self-declared vocalists responded when invited to participate in the study. The different experiences and knowledge of vocalists compared with instrumentally trained musicians/teachers might influence grade level preference and results of this investigation. Only eight teachers were interviewed. A larger pool of respondents would add to the findings that emerged in the present study. 


\section{DEFINITION OF TERMS}

Arts-In this paper, when discussing the Arts, it is to include music, art, dance, and drama.

Arts \& Humanities - In Kentucky, arts and humanities consists of music, art, dance, and drama. All four areas are required participants to be taught in schools P-12.

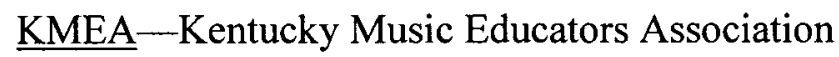

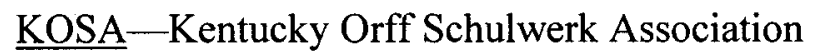

MENC-Music Educators National Conference: the National Association for Music Education.

P-12-In Kentucky, this describes all levels of teaching from elementary school (primary) through high school $\left(12^{\text {th }}\right.$ grade). Most music education majors are certified to teach all levels even though they may have a preference for a specific age level.

Phenomenological Study - This type of study describes the meaning of experiences of a phenomenon for several individuals. In this study, the researcher reduces the experiences to a central meaning of the "essence" of the experience (Creswell, 2007, p. 236).

Qualitative Research - This is an inquiry process of understanding based on a distinct methodological tradition of inquiry that explores a social or human problem. The researcher builds a complex, holistic picture, analyzes words, reports detailed views of informants, and conducts the study in a natural setting" (Creswell, 2007, p. 249). 


\section{CHAPTER TWO \\ REVIEW OF LITERATURE}

At the beginning of the research process, the investigator should carefully review literature in the field she plans to examine. Creswell (2005) explains that this process will help prove there is a need for your study and will build upon existing knowledge. When reviewing literature pertaining to music teacher's preference to teach at the elementary level, topics pertaining to one's desire to teach music as well as the desire to teach at the elementary level we examined. Life experiences also affect personal preferences and desires, so the investigator examined literature from three different life stages: pre-college experiences, teacher training experiences, and career experiences. The organizational flow of these categories can be found in Figure 1 below.

\section{Figure 1}

\section{Literature Map}

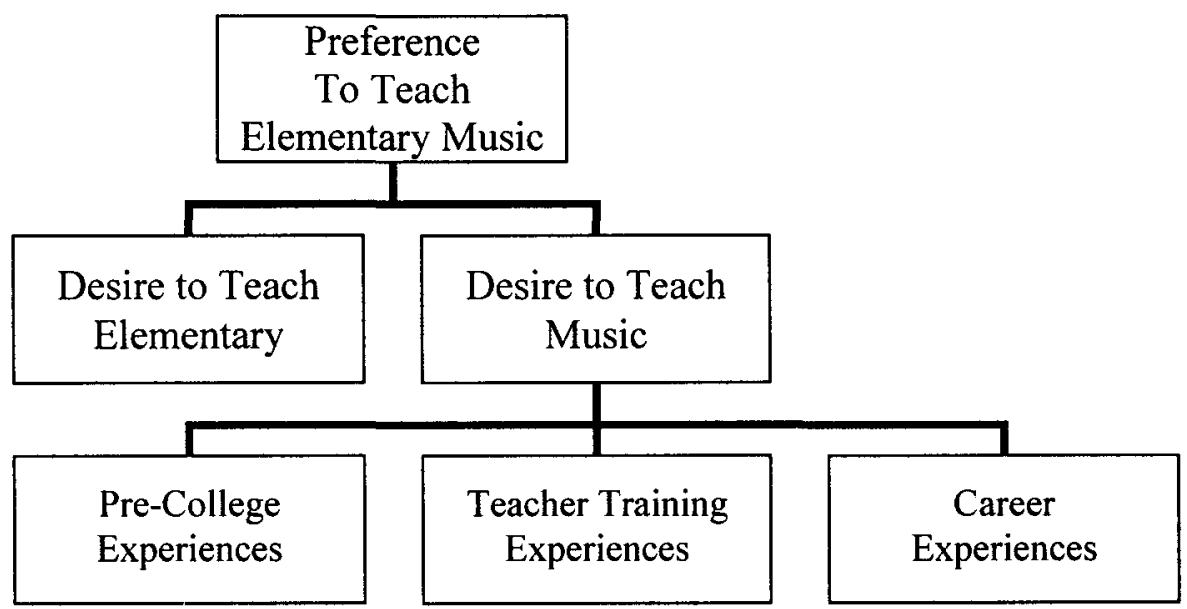


The set of studies included in the review of literature addressed these topics in the field of elementary music educators. However, the research results also revealed gaps in the research field and a need for further study.

\section{DESIRE TO TEACH ELEMENTARY}

Before narrowing the research down to elementary music teachers, the researcher first examined the field of elementary education as a whole. Examining reasons why students pursue the field of elementary education may shine light on the preference for elementary music education. The following studies explore these influencing factors as well as gender issues in the field of elementary education and cognitive styles common among elementary teachers.

\section{What Influences the Desire to Teach Elementary?}

Valadez (1998) conducted a quantitative study of non-music educators to discover the factors influencing the decision to pursue an elementary education degree. Seventyone student teachers from Texas private universities were invited to complete a questionnaire using the Likert Scale; 54 questionnaires were returned for a response rate of $76.05 \%$. After receiving the completed questionnaires, follow-up interviews were conducted by telephone with topics prompted by questionnaire responses.

Factors influencing nearly all the participants to pursue elementary teaching were: the desire to impact children's lives (98\%), enjoyment working with children (98\%), and a sense of accomplishment when seeing a child has shown progression (96\%). Most participants valued these intrinsic factors rather than extrinsic motivators such as money 
or recognition. Seventy percent of the respondents named job security, fringe benefits, and salary as having some significance or less. Although these responses are common among nearly all the participants, they are not factors specifically unique to elementary education.

A teacher at any grade level can impact children's lives; however, elementary teachers are typically seen as setting a foundation of information, experiences, and study skills needed for more advanced study. Jerome Bruner explains this "spiral curriculum" in his book The Process of Education (1960) - any subject can be taught to any child in some honest form.

"If one is courteous enough to translate material into his logical forms and challenging enough to tempt him to advance, then it is possible to introduce him at an early age to the ideas and styles that in later life make an educated man." ( $p$. 52)

Bruner points out that it takes a special person who can successfully relate material to children of a younger age. His only reasoning to determine who would be successful at the elementary level was that they have a natural attraction to children of this age.

In the same study, Valadez reported fifty-one percent of the respondents $(n=36)$ noted the influence of a former teacher as having the greatest significance on their decision to pursue elementary teaching. However, Valadez's study did not give much detail on whether these were high school or elementary teacher role models. Perhaps a qualitative research design would provide more insight on these personal experiences.

Other common responses noted in Valadez's work were the opportunity to be creative (54\%) and the freedom to make one's own decisions (57\%). Although elementary teachers may feel like they can be more creative in their teaching, secondary 
teacher may also argue that they are creative in their teaching. These responses, again, do not provide a full insight on why teachers prefer to teach at the elementary level rather than the secondary level. Valadez's study does cite case values of teachers that can be projected s elementary educators.

\section{Gender Imbalance in the Elementary Profession}

Johnston, McKeown, \& McEwen (1999) examined the gender imbalance in the field of elementary education. The researchers used focus group discussions to gather data on common factors influencing the choice to pursue elementary teaching. The twelve most common responses were included in the design of a questionnaire where participants were asked to rank them in order of importance. Freshman, sophomore, and junior elementary education majors ( $n=334)$ completed the researcher's questionnaire. Of the participants, $85 \%$ were female and $15 \%$ were male. Males and females agreed on most responses. Both genders placed the highest value on four key factors: working with children, perceived job satisfaction, contribution to society, and imparting knowledge. However, there was a significant difference in the importance of working with children $(p$ $<0.05)$ and the importance of salary $(p<0.001)$. Females placed a higher importance on working with children while males placed a higher importance on salary. Johnston, et al., suggested females value more intrinsic factors and males value more extrinsic factors. Like Valadez, a love of teaching children of this age and satisfaction with achievements are key values in people pursuing careers in elementary education.

Another section of the questionnaire made reference to the participants' attitudes toward teaching. When asked if females are 'better' primary teachers than males, $42 \%$ of 
females agreed and $28 \%$ of males agreed. When asked if males are 'better' secondary teachers than females, only $9 \%$ of females agreed, but $40 \%$ of males agreed.

The results indicated that some males have an internalized notion of "femaleness" with regard to primary teaching. Some male participants in the focus group had expressed their need to contribute a male presence in primary teaching as a way to counter a perceived female dominance in elementary campuses. None of the participants in this study were music education majors, but such gender issues are important to consider.

\section{Cognitive Styles of Elementary Teachers}

The cognitive style of an individual significantly affects the choices he or she makes. Shindler (1998) examined the cognitive styles of pre-service teachers to discover what kinds of people are attracted to teaching at the elementary level. Undergraduates $(\mathrm{n}=219)$ were given a learning/cognitive styles inventory, the Paragon Learning Styles Inventory, to measure cognitive dimensions. Results indicated that $74 \%$ are more structured, sequential thinkers rather than spontaneous, flexible thinkers. Closely related, $60 \%$ were more concrete-minded opposed to abstract thinkers. This seems to contradict the previous findings from Valadez (1998) which found that over half were attracted to the creative aspects of the field and the freedom to make their own decisions in the classroom. Again, neither of these studies included elementary music teachers, and the Valadez (1998) study included only one art teacher. The Arts require creativity; perhaps further research in the cognitive styles of elementary teachers with a different sample including teachers in The Arts might yield different results. 


\section{DESIRE TO TEACH MUSIC}

Upon entering college, a student may have a general idea of what career they would like to pursue. Hopefully, before graduation, the courses and experiences throughout their undergraduate career will help narrow their focus to a more specific field of study. In the field of music education, most students must obtain a degree which certifies them to teach music to all levels-elementary, middle, and high school. Even though they will be certified to teach at any level, nearly all music teachers have a preference for an age level as well as a preference to teach general music or an ensemble like band, choir, or orchestra when they enter college. The following studies explore the reasons why students choose to enter the field of music education and successful recruitment strategies for the field of music education.

\section{Initial Attraction to the Field}

Recruiting music teachers is a topic of concern to Music Educators National Conference (MENC) ("Recruiting for the Profession," 2000). This article states that many music educators mention the influence of a particular music teacher when they decided to enter the field of music education (p. 24). "Recruiting for the Profession" encourages ensemble directors to actively recruit promising individuals with a combination of musical and personal qualities that would make a person a good music teacher. If high school music teachers are actively recruiting future music educators, will the students be more attracted to teaching at the high school level?

A qualitative study by Bertke (2008) interviewed college freshman ( $\mathrm{n}=11)$ to determine what experiences influenced their decision to pursue a degree in music 
education. When asked to recall musical experiences from their past, most of the responses referred to experiences in middle or high school ensembles. These memories were both positive and negative. The students who came from strong music programs wanted to recreate this classroom environment when they become teachers. Lautzenheiser (2001) explained many college music education students are planning to replicate the lives of their high school role models.

Perhaps these directors were indirectly recruiting for the profession by serving as positive role models. The respondents who came from weak music programs with weak leadership (often with multiple changes in directors) were motivated on becoming a teacher so that they can provide a better experience for their future students. Even without active recruiting by a successful ensemble director, students are still attracted to the field of music education.

When asked to comment on their future role in the field of music education, all of the respondents stared the desire to become an ensemble director at the secondary level. One respondent, however, admitted they first wanted to teach high school band, but now that they are keeping their mind open to options within the field of music education. The student did not elaborate on what had changed their outlook.

None of the eleven respondents shared experiences from their elementary music classes at any time throughout the interview. Is it possible for an elementary music teacher to recruit for the field of elementary music education? Will the distant memories of elementary music class even cross their mind as they are choosing their career path? None of the respondents mentioned activities from their elementary school, perhaps because it was such a long time ago. 


\section{Reluctance toward Elementary Music Methods}

Debra Gordon (1999) explains that the shaping of a teacher is a delicate process as perspectives, attitudes, and beliefs can be influenced in the pre-service years. In her article, "The metamorphosis of a beginning music educator," she explains that, after many years teaching an elementary general music methods course at the University of Northern Iowa, she found that the majority of the music education majors view themselves as potential high school music teachers. She rarely receives a student who prefers elementary teaching before they have completed her methods course.

Typically, Gordon's elementary methods course consists of twenty instrumental and choral majors and one or two piano majors, all with a desire to teach general music. Prior to the elementary general music methods course, Gordon explains that students may not be drawn to elementary music due to their lack of experience working with young children and their unawareness of the importance of the early stages of music education. After observing elementary students, writing lesson plans, and peer teaching, Gordon reports that a definite change in the students' attitudes mid-semester. Most students gain confidence in teaching elementary music and become more open to the possibility of a career at the elementary level.

The majority of the Gordon's article includes narrative research describing one student, Molly, who only wanted to become a high school band director and dreaded the elementary methods course. She entered the course in the fall with a negative attitude, but by the end of the course and after her student teaching at an elementary school her strong opposition had disappeared. Upon graduation, she accepted a job teaching band at three elementary schools and one high school. She later confessed to Gordon that, 
although she was excited to teach high school students, her most rewarding and enjoyable experiences occurred at the elementary level.

Many teachers entering the job field after graduation may accept an elementary position out of necessity when their preference was to acquire a job at the secondary level. What experiences may influence them to remain at the elementary level and possibly change their preference?

\section{Pre-service Teachers' Images of Teaching}

Observing 43 first- and second-year music education students, Campbell (1999) reports on how novice teachers' beliefs and images of teaching music change as they complete their methods courses and field work. The students' most recent experiences prior to college have most likely been performance-based. Upon entering the field, students describe their image of a music teacher as "fun and friendly" and "making connections with students." Images of themselves as directors and modelers of skills appear often in their discussions. They rarely picture themselves teaching content or imagine teaching as anything more than "having fun."

Campbell highlights the experience of one student who became interested in teaching elementary after taking her general methods class. Beginning her student teaching, she felt confident in her musical skills and her abilities to "share the joys and fun of making music." She soon became frustrated when lessons did not go as planned because she couldn't get them to pay attention. Initially, she struggled with classroom management, dealing with behavioral issues, and gaining student interest. Campbell observed her transformation as she established a sense of authority in the classroom and 
realized that teaching was more than simply "having fun." She later described her image of a teacher and explained that a teacher must find a balance between what you plan, what you do, and how you do it. She realized that her plans could only be a guideline; she must reflect during instruction and modify to fit the needs of her students.

In this case, the student was able to learn how to teach and successfully transform from the role of a student to the role of a teacher. She finished her degree program with confidence that she was ready to enter the field of teaching. Some students are not as lucky and take longer to acquire confidence in their teaching skills. They may not feel they have "learned to teach" until several months or even years into their teaching career. If a student had an unsatisfactory experience while student teaching, what experiences on the job may influence their decision to continue pursuing elementary teaching?

\section{Gender Imbalance in Elementary General Music}

Roulston and Mills (2000) have investigated the male perspective working in this feminized environment. The study "Male teachers in feminised teaching areas: marching to the beat of the men's movement drums?" proposes that males may not be as comfortable singing for several reasons, but mainly argues that singing is not perceived as a masculine activity in western society. Perhaps one reason males are not attracted to the elementary level is because singing is an integral part of elementary music. They may lean more toward conducting instrumental and choral ensembles at the secondary level.

Roulston and Mills stressed that males need to start singing early in elementary school and need strong male role models to avoid the stigma attached to singing. One teacher highlighted by their study explains that he decided to teach elementary music as 
counteraction against the stereotype. He knew that he would be in the minority, but felt he could serve as a strong male role model. The overabundance of the female gender in elementary music can both deter and encourage males to enter the field.

\section{Pre-Service Music Teachers' Intentions}

Hellman (2008) surveyed 152 pre-service music teachers on their intent to enter and remain teaching music at the K-12 level. His survey included forced-choice and open-response items. Hellman reports that $86.6 \%$ of the students intended to enter the career of music teaching. Consistent with Gordon's report (1999), 84.2\% would like to teach an ensemble and only $63.2 \%$ would like to teach general music. This causes a problem in the job field because there are typically more general music positions than ensemble directors in public schools P-12. Many teachers entering the field may prefer to teach at a secondary school but end up teaching general music at an elementary school out of necessity rather than initial preference. In this case, how many of these teachers move on to a secondary job as soon as a job becomes available and how many decide to stay teaching at the elementary level? No research was found to answer this question in this literature review.

Hellman also reports that males tend to choose high school teaching at a much higher rate than that of females (68.2\% versus $30.6 \%)$. Males also choose elementary teaching at a much lower rate than females ( $4.5 \%$ versus $32.9 \%)$. Females choose between elementary and high school at almost an even rate ( $32.9 \%$ versus $30.6 \%)$. The difference between male preference for high school and elementary is much more significant $(68.2 \%$ versus $4.5 \%)$. Male music teachers who prefer elementary music are 
then a minority. Hellman's survey provides some interesting statistics, but it does not address the reasons behind these gender trends. What attracts females to the elementary music profession so strongly? What influences the minority of males who prefer to teach music at the elementary level?

\section{Finding an Identity as an Educator}

Before choosing a career path, one must understand their professional identity. Rhoda Bernard, of the Boston Conservatory, guides her music education students into discovering their professional identities through narrative reflection. In a case study, Bernard (2009) explains that students often struggle with making meaning of their identities as musicians. As assignments in her courses, she asks her students to write autobiographical narratives about music teaching, music learning, and music making. As the students complete these assignments, they must reflect on these experiences and how they have shaped their professional identity.

Bernard has collected and analyzed these stories for many years. However, it is not evident that she has ever contacted these students after graduation. Further research could be done to determine whether this reflection has helped the students select the correct career path or if the students' personal identities have been altered after a few years in the field.

In terms of the current project, Bernard's suggestions were applied to the design of the interview questions. Bernard suggests students examine every aspect of their musical past to determine what musical career they would like to pursue. The interview questions explore participants' musical experiences in childhood, college, and post-college. They 
also lead participants to discuss experience in school and outside school. By examining all these experiences, the researcher can best determine what has shaped each participant's musical identity.

\section{Individual Career Experiences}

Ella Wilcox has published a series of articles highlighting extraordinary music educators (Wilcox, 2003, 2004, 2005). In these articles she describes the teaching style of the individuals, their history in the profession, and other life experiences as teachers. In her first article, “A Mid-Career Teacher's Juggling Act” (Wilcox, 2003), she describes how Nancy Anderson, an elementary music teacher in Virginia, balances her career with the role of motherhood. Although she does not specifically address why she decided to pursue elementary teaching, it is evident that she enjoys being around children. She warns young students who want to become teachers, "You'll need to develop certain skills, such as the ability to relate to kids." Previous findings suggest the enjoyment of children is a key factor in attracting teachers to the elementary field (Johnston, et al., $1999 \&$ Valadez, 1998). Anderson has stressed this same quality as a key factor to becoming a successful elementary music teacher.

Her second article, "More Than a Living: Teaching in an Urban School," (Wilcox, 2004) focuses on Claudine Nash, an elementary music teacher in an urban setting. She was born and raised in the District of Columbia. Her family was very poor, but many of her music teachers recognized her talent and eventually encouraged her to pursue a degree in music. She was able to get scholarships to pay for college. Claudine is very thankful for the encouragement from her music teachers and it inspired her to 
become a teacher and role models for others as well. She enjoys seeing "up-and-coming young artists" and mentoring them through life. This case study confirms previous findings that role models strongly impact the choice of a career path (Bertke, 2008; Campbell, 1999; Hellman, 2008; Lautzenheiser, 2001; \& Recruiting for the Profession, 2000).

\section{SUMMARY}

College seems to be a central stepping stone for students to choose their specialty and narrow their field of study to a specific career path. For the music education major, this is a time to develop preferences for an age level (elementary, middle, or high) and also preferences to teach general music at the elementary level or lead an ensemble. In this review, many studies (Bertke, 2008; Gordon, 1999; \& Hellman, 2008) indicate that more prefer to teach at the secondary level as ensemble directors, even though there are more job positions as elementary.

Statistically, more females choose to enter the elementary profession (Hellman, 2008; Johnson, et al., 1999; \& Roulston \& Mills, 2000). This gender stereotype may dissuade some males, but it may inspire others as a chance to become a positive male role model and try to overcome the stigma.

Shindler examined cognitive styles of elementary teachers to determine what personality qualities may lead one to prefer elementary, but none of the participants were music teachers. Research has been done to discover how elementary music teachers develop their professional identity as teachers and musicians (Bernard, 2009 \& Campbell, 
1999), but has not addressed the reasons behind their preference to teach at the elementary level.

The current study advanced these ideas by sampling a small set of current elementary music teachers from rural school districts who have many different backgrounds and teacher training experiences. This study identifies, on a qualitative level, those experiences which influence music teachers' preference to teach the elementary level. 


\section{CHAPTER THREE \\ RESEARCH DESIGN AND METHODOLOGY}

\section{OVERVIEW}

Schwandt (2001) explains that qualitative research aims to understand the "meaning of human action" and relies primarily on data in the form of words (p. 213). Creswell (2007) further explains the qualitative researcher builds a complex, holistic picture, analyzes words, reports detailed views of informants, and conducts the study in a natural setting (p. 249). I choose a qualitative approach for this study so that I could examine each individual's personal experiences at a much deeper level to understand how these experiences influenced their careers as elementary music teachers. This qualitative study further applies a phenomenological approach as defined by Creswell (2007) —a study that describes the meaning of experiences of a phenomenon for several individuals by reducing the experiences to a central meaning of the "essence" of the experience (p. 236). This study employed interviews, thematic analysis, coding, and transcription. Data/interview responses were collected and analyzed by the researcher for themes.

The purpose of this study was to examine the experiences of current general music teachers to determine what most influenced them to pursue their current positions in elementary teaching. There are three research questions addressed in this study-

1) What experiences do they describe from their childhood or during their collegiate career that influenced their desire to teach music at the elementary level?

2) What experiences as an elementary music educator have influenced their decision to stay or leave the elementary level? 
3) How do these experiences affect a person's satisfaction as an elementary music teacher?

\section{PARTICIPANTS}

This study was originally designed with a purposeful sample to be homogeneous. It was to include 11 elementary general music teachers currently teaching in one particular rural public school district neighboring a major metropolitan area. Selection of this district was chosen out of convenience, although similar districts do exist near the site of current investigation. Recruitment letters were sent via email. Few teachers chose to participate $(n=8)$. Also affecting the sample were two of the music positions which were changed to Arts and Humanities positions. These new teachers did not have strong musical backgrounds and were not included in the study since they could not be clearly defined as music teachers only. In order to attain an adequate sample, the invitation to participate in the study was extended to elementary music teachers in neighboring rural counties. The final sample of participants $(n=8)$ include six females and two males ranging from ages 27-56. The years of teaching experience ranged from 2-13 years with the average being seven years (See Table 1).

\section{Table 1}

\section{Participant Demographics}

\begin{tabular}{llllllllll}
\hline Participants & 1 & 2 & 3 & 4 & 5 & 6 & 7 & 8 \\
\hline Gender & F & M & F & F & F & F & F & M \\
Age & 56 & 47 & 28 & 40 & 34 & 27 & 28 & 29 \\
Years Teaching & 6 & 13 & 10 & 10 & 10 & 2 & 5 & 7.5 \\
\hline
\end{tabular}


It should be noted that all of the participants had an instrumental background as discovered by initial surveyed questions. This was not the intent of the research design and was not discovered until analysis of the data. The absence of the choral perspective should be noted.

\section{PROCEDURE}

Following approval from the university's Institutional Review Board, elementary music teachers identified for the study were invited to participate by email or telephone. The interviews were conducted at the actual participants' place of employment and in their music classrooms when possible. Some interviews were conducted via telephone due to inclement weather. Interviews lasted approximately 30 minutes. All participants signed an IRB approved consent form prior to answering any questions and had the right to decline to answer any question at any time.

I designed the interview questions to include all three areas included in the Review of Literature - pre-college experiences, teacher training experiences, and career experiences. I asked participants to verbally respond to questions about their career background, music teacher identity, teacher training experiences, professional development, and their experiences as an elementary student in music class. The interview questions guiding the interviews are listed below in Table 2. 


\section{Table 2.}

\section{Interview Questions}

\section{Background Information}

1. How long have you been a teacher?

2. Where did you get your teaching training? What is your official degree certification?

(K-12, vocal, instrumental, general)

3. What was your major performing area? (vocal/instrumental)

4. How long have you been in this school?

5. Is this your first teaching position?

6. Have you taught at any secondary schools?

7. What grades and ensembles do you currently teach?

8. Do you teach anything other than music?

\section{Music Teacher Identity}

9. What attracted you to your current position?

10. What do you like about teaching elementary age children?

11. Do you have a preference for a particular age or grade level? Why do you suppose that is?

12. Do you feel that you are successful as an elementary music teacher? How so?

13. What kinds of activities do you most like doing with your children? Are these things you learned in college, workshops, remembered from childhood, or something else?

14. What is your most memorable experience as an elementary music teacher in the past few years?

15. When did you decide you wanted to teach elementary music?

16. Do you hope to continue teaching at the elementary level for an extended time?

\section{Teacher Training Experiences}

17. Think back to your first year teaching. Did you feel like you were prepared to teach elementary music?

18. Are there things you wished you had learned before you started as an elementary music teacher that you did not learn in college? Where were the gaps?

19. What was the most valuable experience during your college training that helped prepare you to teach elementary music?

20. Do you think there were other experiences outside of college that have helped prepare you to teach elementary music?

Professional Development, since college

21 . What have you done to learn more about teaching elementary music since your college days?

22. What do you currently do to improve your teaching and musicianship? (attend workshops, conferences)

23. Do you have a mentor, peer, or support group that you turn to for advice about teaching elementary music?

\section{Elementary Music Background}

24. Are there any musical experiences you had as a child that you are now sharing with your students? 25 . How does your current elementary music classroom compare to your experiences when you were a student in elementary school?

\section{Summation}

26. Is there anything else you would like to share regarding your preference for elementary music that we have not yet discussed? 
All participants answered the questions as they appear above. However, I often included additional questions when further explanation, clarification, and probing were needed, as is appropriate in qualitative designs. Question 26 , for instance, allowed participants to add additional thoughts or experiences pertaining to their experiences in music training and teaching. Not all participants did this. Participants were also invited to contact me by telephone or email if they wished to add to their initial responses, but none did so. The interview questions did not include the age of the participants. I contacted the participants by email for this data and all volunteered this information.

During the interview, I was careful to ask all questions as they were written on the interview protocol with slight variations as needed for each teacher (See Appendix A).

\section{DATA ANALYSIS}

The interviews were tape recorded to create transcripts of the discussion (See Appendix B). When transcribing the tapes, I was careful to include an accurate record of the participants' responses. I often included ellipses during significant pauses and utilized capital letters to show emphasis by the participant. I also noted laughter by the participants, inserted with brackets.

I listened to the tapes and read the transcripts several times during analysis. In the margins of the transcripts, I labeled each section with a phrase which quickly explained what each participant discussed during that passage. I used a different color pen for each phrase so I could visually see how the change of topics flowed throughout the interview and also so I could compare the phrases among several different participants. As Creswell (2007) suggests, significant phrases were identified in each transcript to identify 
experiences directly or indirectly relevant to participants' pursuit of teaching music at the elementary level (p. 61). Many of these significant phrases are quoted in the results and used to help explain the analysis.

Last, I developed clusters of meaning, which Creswell (2007) defines as "data analysis in which the researcher clusters the statements into themes or meaning units, removing overlapping and repetitive statements" (p. 235). Some phrases were repetitive and explained similar experiences or outlooks and were clustered into themes that emerged as common among all or many of the participants. For example, the following phrases were used when participants were asked why they prefer to teach elementary children and if they favored a particular grade level: "students' excitement," "students love you," "students are willing to do anything," "children's personalities," and "we have fun." All of these phrases are similar and were grouped into a larger theme Interest in Young Learners. All participants mentioned personality traits characteristic of younger children when describing what they enjoy most about teaching. Some of those phrases are quoted and used as examples to support the theme.

After developing the themes, I contacted the participants with the findings to conduct member checks and ensure the accuracy of the analyses. Schwandt (2001) explains this important procedure corroborates and verifies the research findings by soliciting feedback from the respondents on the inquirer's findings (p. 155). None of the participants disagreed with my analyses. 


\section{CHAPTER FOUR \\ RESULTS}

Upon analysis of data, themes were developed based on common statements. The themes are listed below in Table 3 .

\section{Table 3}

Themes

\begin{tabular}{|c|c|}
\hline 1. Childhood Enjoyment & $\begin{array}{l}\text { Most participants did not enjoy their experiences as children in } \\
\text { elementary general music. (Only one participant described a } \\
\text { positive experience.) }\end{array}$ \\
\hline 2. Pre-service Preference & $\begin{array}{l}\text { Many participants (half) developed a preference to teach } \\
\text { elementary music while in college. }\end{array}$ \\
\hline $\begin{array}{l}\text { 3. Post-college } \\
\text { Preference }\end{array}$ & $\begin{array}{l}\text { Many participants (half) developed a preference to teach } \\
\text { elementary music after accepting a teaching position at the } \\
\text { elementary level. }\end{array}$ \\
\hline $\begin{array}{l}\text { 4. Value of Field } \\
\text { Experience }\end{array}$ & $\begin{array}{l}\text { All participants valued their field experience, observing and } \\
\text { working with elementary age children. }\end{array}$ \\
\hline 5. Creative Opportunities & $\begin{array}{l}\text { Most participants enjoy the creativity and freedom in an } \\
\text { elementary music room; most referred to the creative approach in } \\
\text { Orff-Schulwerk. }\end{array}$ \\
\hline $\begin{array}{l}\text { 6. Interest in Young } \\
\text { Learners }\end{array}$ & $\begin{array}{l}\text { All participants mentioned personality traits characteristic of } \\
\text { younger children when describing what they enjoy most about } \\
\text { teaching. }\end{array}$ \\
\hline 7. Value of Ensembles & $\begin{array}{l}\text { Many participants' most memorable experiences were of ensemble } \\
\text { performances and not in the general music classroom. }\end{array}$ \\
\hline
\end{tabular}




\section{THEME ONE: CHILDHOOD ENJOYMENT}

The most striking theme found among the participants was their negative experiences as children in elementary music class. When asked to compare their current music classroom to their own past experiences, most participants replied that there was nothing similar. Many of the teachers did not view their elementary music class as a worthwhile experience.

Participants often described their own elementary class experiences as simply singing songs and passive teaching. Participant 4 reminisced, "We would walk in in line [sic], we would pick up a book, we would sit in a chair, she would play a record, and we would leave. We would just sing." Participant 2 recalled, "the music teacher came around on a cart with books and we sang," but also offers a defense for his former elementary music teacher, "It was just singing. Which is fine, I guess it's just the way they did it back then."

A few participants offer explanations as to why they did not enjoy their music class as a child. Participant 5 describes her experience as very boring:

"I remember elementary school music was sit in a chair and they passed out book, and we sang songs out of it. There were a few instruments, maybe some rattles or something, but that was pretty much it ... We did do a lot of dancing, like square dancing, I can remember. Other than that, it was pretty sedentary and just singing." [sic]

Four of the participants also described their disappointment in the strong emphasis in singing. However, it must also be remembered that all of the participants who participated in this study were trained instrumentalists. If the sample had included 
elementary teachers with a vocal emphasis, perhaps the responses would have indicated the opposite.

Participant 6 seemed to address this question from a teacher's perspective instead of a student's perspective:

"I am a MUCH better music teacher than my music teacher was. And I don't say that to brag, I just remember that all we did in elementary was-in the spring, we would get ready for the spring musical and in the fall, we would get ready for the winter musical. And they were always like these big musical collage things. We never learned about notes and rhythms. All that I learned in band."

Participant 6 has a very different perception of music learning than that of her former elementary music teacher. She places a high value on reading music and learning notes and rhythms instead of simply performing from rote. She does not feel like her experience was worthwhile because she did not actually learn what she now feels is valuable content. Participants 1 and 8 both shared that they remember watching a lot of videos that didn't offer any educational value.

Many participants could not remember much about their own elementary music experience. Participant 8 confessed:

"I would like to think it's MUCH better ... because there's just so little I remember from my own background. You know, I couldn't even tell you who my old music teacher's name was . . . to be honest. Um, so, I'm hopeful that I can create some pretty vivid memories and experiences. And I try to just do ... something that's meaningful every day. I don't think I had that because I can't remember it ... at all. So, hopefully it's much better than what I had."

His disappointment in his own experience has inspired him to become a better teacher for his students. 
When voicing these negative experiences, a few participants showed disappointment in their former music teachers. Participant 6 describes her feelings as she reflects on her experience:

“...when I went back and visited my elementary music teacher as I was going through my teacher preparation program at UofL [University of Louisville], I found that I already had a better grasp at teaching than he did. And that's a hard thing to realize, because you think your teachers are just the most awesome thing in the world when you're a kid."

As a child, she may have enjoyed his music class; she described participating in many musicals. However, as a fellow teacher in the profession, she compares their teaching philosophies and realizes how greatly they differ in delivery styles.

Only one participant described a positive elementary music experience from childhood. Participant 7 explained that her elementary teacher was memorable and included the Orff approach in her teaching.

"I'm fortunate enough that my elementary music teacher is one of my colleagues. And so, I've pulled a lot of things from her and things of that sort. You know, she still has certain ways of doing things and mine is definitely different. I tend to focus a lot on, or try to focus, on technology and creative ways of getting information to students. Her approach is much more Orff-oriented and mine's kind of more of a mixture."

She acknowledged that she was fortunate and realized her situation was not the norm.

Nearly every participant shared views of negative experiences in elementary music class. Some of these participants viewed their music class as boring. Despite this negative outlook, these early experiences shaped the individuals; these seminal moments may have influenced their preference to teach music at the elementary level in attempts to 
improve the field of elementary education. Some of the participants came to this realization during college as they began developing their own teaching philosophy.

Roulston and Mills's study (2000), noted in the review of literature, explored gender imbalance in the elementary music profession. One male teacher chose to teach at the elementary level after noticing a lack of male role models for young boys. Most of the participants in this study describe their own classroom as an exact opposite of their own experience. Perhaps, these memories motivate them to provide a better experience for their students.

\section{THEME TWO-PRE-SERVICE PREFERENCE}

Four participants $(1,2,6 \& 7)$ indicated that their decision to focus on elementary music was made toward the end of their college training. Confirming Gordon's (1999) results from the review of literature, three participants indicated specifically that they preferred elementary as a result of experiences in their elementary general methods course. Participant 1 describes how the course was not what she expected:

“... probably junior year in college when I had elementary methods and I realized how much fun you could have with them and how ... how much REAL music you really can do with them. I think I at first wasn't sure that you can make elementary music meaningful because my elementary music was so superficial, I feel like. So, but, when I learned, yeah, how much you can do with them, I thought, 'Well, this could be interesting.' So I think that was the first time I thought, "Oh, I could do this."”

Since she had a poor experience in elementary music class, she was surprised at how many different activities could be done. Seeing how activities could be structured to foster learning changed her outlook on teaching children. 
Participant 7 explains that her elementary methods course was helpful because she had a wonderful professor:

"I had a VERY, VERY good professor who taught that class at the time and she was lovely and very much into the kids and that really kind of shone through. And that made you want to be the same way and be creative and have fun with it."

Her professor modeled lessons with actual children, which is unusual. Most college students do not get to work with children until student teaching. Such observations influenced Participant 7's ultimate interest in elementary music education.

Several respondents did not truly discover an affinity for P-6 teaching until actually working with this age. Campbell (1999), from the review of literature, explained a similar situation where a student began to prefer elementary teaching during field experience working with children. Participant 6 found her elementary methods course helpful, but she claims it was not until student teaching at an elementary school that she decided she liked elementary level.

“... one of the reasons that I really like elementary was after I took the elementary methods class and my student teaching. ESPECIALLY, after student teaching I realized that this would not be a bad thing at all. I like the age group. I like the freedom. There are so many creative options when teaching elementary." "The methods course in college gave me the hint, 'Yes, this might be doable ...' After student teaching in my graduate year I said, 'Yep, I can do this!”

Courses in elementary methods usually involve peer teaching. These experiences can be helpful, but teaching children is different than teaching to fellow classmates. During student teaching, Participant 6 got to work with children and that experience influenced her decision to teach at the elementary level. 
The literature review yielded similar findings. As a professor of music education, Gordon (1999) has observed over the years that many students begin the semester apprehensive about teaching at the elementary level, but by the end of the course most students open up and welcome the idea.

\section{THEME THREE-POST-COLLEGE PREFERENCE}

Four participants $(3,4,5, \& 8)$ indicated that their decision to focus on elementary music was made after accepting a teaching position at the elementary level. Participant 4 spoke negatively about her elementary methods course. She explains that she did not like the professor and so she did not appreciate the class:

"Because I think it was one semester, that's all we got 'cause we were instrumental, one semester of him teaching us ... some of these theories, elementary music theories. I had him as a professor and I did not appreciate who he was and what he did. And I just knew I was going to teach band and I didn't need that."

This second theme illustrates how the elementary methods course can impact deciding an area of focus. Participant 4 also confirms Gordon's article (1999) from the literature review that many students enter the methods course with a negative outlook. She hesitantly accepted an elementary position and soon discovered she preferred it:

"Um, after I had been here the first year, I decided to come back the second! I have to admit, I was going to be a high school band director. Oh, I wanted to be a middle school band director and an assistant to a high school because clarinet was my life! And after being here a year, and looking back on that year, I was amazed at how nice it was not to be going toward a performance and being able to teach. It was actually after I taught a year." 
Participant 4 spoke very passionately about teaching elementary throughout her interview. She took a chance and was willing to try an elementary position. She has now taught there ten years and says, "I plan on being here twenty more years!"

The first job accepted by Participant 3 was in a small K-12 school. She explained that did not enjoy teaching elementary students at that time because she didn't have many resources or instruments. She describes her initial experiences elementary music teacher:

"I was the first music teacher they had ever had. There was no material. It was pretty much, you just grope your way along. And I don't think that was a very fair accounting of elementary music." [sic]

After a few years out of the profession staying home with her children, she reluctantly accepted another elementary position. She was surprised when she found out that she enjoyed teaching in the elementary level:

"Yeah, it was the job that came open. And I almost didn't apply for it because I just felt more comfortable with older kids. But, my children all went to and I just really loved the school. I thought, 'Well, ... I'll try.' I think as much as anything it was a little apprehension and not really knowing what to do with them - not being sure that I could relate to little bitty ones because I ALWAYS preferred the older kids. I always like middle schoolers. I think as much as anything it was just apprehension, thinking maybe I can't do that."

She also states, "I think, at this point, I wouldn't teach anything but elementary."

Participant 5 was first employed at a K-12 school and was responsible for teaching a high school band, middle school band, and $5^{\text {th }}$ grade beginning band. She began to change her interest in the elementary students, explaining, "They're always excited to try new things. Not afraid to take risks ... just enjoyable to be around." She has been teaching at the elementary level for the past 7 years. Initially, she wanted to be a 
high school band director, but now she cannot see herself working with any level other than elementary.

These four participants discovered that they preferred elementary after working with them either part-time or full-time. They all claimed they wanted to be high school band directors; this common trend was also confirmed by Bertke (2008), Gordon (1999), and Hellman (2008) from the review of literature. After teaching a year at the elementary level, they realized they preferred working with younger children. They certainly had to complete student teaching at the elementary level, but often this is only for one half of a semester. Perhaps, if the student teaching experience was longer, they might have discovered their love for elementary before entering the job field.

\section{THEME FOUR - VALUE OF FIELD EXPERIENCE}

All participants valued their field experience observing and working with elementary age children. Participant 3 reflects on the most beneficial part of her college training.

"Well, it wasn't any of those dreadful education classes! Those were terrible! We got to go over a few times at model labs which was right there on campus and just kind of hang out with kids and teachers. Just watching the teachers interact with the kids, with the students. It really kind of opens you up to what teaching you're going to do. 'Cause you really don't get that in the classroom. You go through all the methods, but once you get into the classroom and see the teachers interact with the kids, that's what it needs to be."

Many of the participants shared this same value for their pre-service field experience.

Participant 5 believes there should have been more field experience in her college training: 
"I think, going to watch an elementary music class. Even though it wasn't much, we got to see how you interact with real students instead of your classmates pretending to be elementary students. So, the field experience."

Participant 6 believed her intensive student teaching provided an extra advantage.

"Um, once again, I have to go back to that intensive student teaching that the MAT program provides. I was able to not only see how the year started with the elementary program, I was able to see how HE used scope and sequence to build his curriculum and also for myself to get a good eight or nine weeks as the sole teacher in control to try out mine."

This participant was describing a unique five-year program in which students will participate in one full year of student teaching during their fifth year, and upon completion, will receive a Masters in the Art of Teaching (MAT). Students in most bachelor programs only participate in student teaching for one semester.

All participants valued their field experience in preparing them for teaching in the elementary classroom. However, four of the participants $(2,5,6, \& 8)$ voiced a concern that there was not enough field experience in their college training. These participants most likely had only one semester of student teaching. Participant 8 realized that did admit, "But, how many credit hours can we make that degree?" It would be impossible to lengthen student teaching in a traditional four-year degree program. Perhaps field observations could be incorporated into existing courses so music education students may see more of what elementary has to offer. 


\section{THEME FIVE-CREATIVE OPPORTUNITIES}

Nearly every participant voiced a love for the creative approaches teaching elementary music, as did participants from the review of literature (Shindler, 1998 \& Valadez, 1998). Participant 8 specifically contrasts this to an ensemble class encouraging all students to keep an open mind in college:

"I would just like to see a lot more of the students be a little bit more comfortable saying, 'its ok to break away from the ensemble route,' a little bit. And just see how creative you can be in a given day. And I bet a lot of them would enjoy it."

He further explains that directing an ensemble leaves very little room for creativity:

"But I think also, as far as the comfort level goes, if you're teaching a middle school band, and I know because I've done this, um, you can hide behind that method book. You know, on Monday we can do lines 1, 2, and 3, on Tuesday we can do 3, 4, and 5 and so on. And there it is. Once September rolls around, we can start prepping for the concert, I mean, you know. It can get in to being fairly predictable ... and safe. I just think if they ... if they can just get over the fact that there's going to be a little uncomfortability for a couple months, what you can end up with is . . honestly, I never though I'd say this, but . . . a much more satisfying end product BECAUSE I'm not trying to get specific notes in a specific order or rarely, if ever. It's 'how can you give me a creative response to this?' and in the end I think that's more useful."

As noted above, Participant 8 originally preferred older students and experienced a transformation after accepting a position at an elementary. This trend was voiced by several other participants $(3,4,5$, and 7$)$.

\section{Creativity in Orff \& Kodály}

Most of the participants mentioned that they favored the creative approaches of

Orff-Schulwerk. With the Orff Approach, "playing instruments, singing, and moving are 
treated as ensemble experiences, requiring mutual awareness in order to create successful musical expression" (Steen, 1992). With such activities, students are not passively involved in their education, but actively exploring the elements of music and dance. Kodály's approach is also valued by general music educators. In her book "The Kodály Method I: Comprehensive Music Education," Choksy (1999) explains the goal of this approach is to develop a love of music that is supported by understanding and knowledge (p. 17). Although musical literacy is a major focus, she further explains that students should also be singing, moving, playing, and listening (p. 20). These activities provide opportunities for students explore music through their own music-making.

Both Orff and Kodály were approaches that the participants cited as major influences in their choice to become elementary general music teachers. Four of the participants $(2,4,5, \& 7)$ had taken teacher training course to become trained Orff teachers. Two of the participants $(1 \& 8)$ mentioned that they plan on taking the Orff classes in the near future. Participant 1 trained in the Kodály approach. All of the participants stated they have attended Orff or Kodály workshops as part of their professional development and found them very helpful. Participant 4 explains how Orff has influenced her teaching style:

"Um, what I like and what I use mostly is my Orff experiences where we take body percussion and words and things the kids give me and we transfer them to rhythm instruments and then to the barred instruments or to recorders. And that was things I learned from my masters classes and getting my Orff certification with my graduate studies."

When asked what activities she most likes doing with her children, Participant 5 simply stated, "Orff, anything Orff." These creative activities would be difficult to apply in an 
ensemble setting. The demands of concert preparation and festivals do not allow much freedom for creativity.

\section{THEME SIX-INTEREST IN YOUNG LEARNERS}

All of the participants mentioned several personality characteristics common to that elementary age range that make teaching very rewarding, echoing ideas by Johnston, et al. (1999), Valadez (1998) and Wilcox (2003) from the review of literature. Three participants $(3,5, \& 6)$ expressed their fondness for their children's excitement. Participant 6 explains it this way:

"I like the fact that they are so eager and excited about everything. If you say, 'Hey kids! We're going to go shovel dirt today!' in a very excited voice, they're going to be excited about shoveling dirt! That makes your presentation very easy sometimes. 'Alright kids, we are going to learn to sing la, sol, mi today and you're going to be awesome at it!' 'Yeah, we're going to be awesome at it!' [student's reply]"

Many teachers would agree it is more rewarding to teach students who are interested and excited about the lesson. When students are interested and even appreciate their lessons, a teacher will also feel successful.

Four of the eleven participants $(4,5,6, \& 8)$ enjoy the children's willingness to try anything new. Participant 4 explains, "It's amazing how ready they are to do everything I ask them to do-sing, dance, play, play instruments, uh, work together, work by themselves. They're just so open to any experience." Participant 5 also enjoys children's eagerness stating, "They're always excited to try new things. Not afraid to take risks ... they're just enjoyable to be around." Participant 8 compares the elementary children to his experiences teaching middle school children stating, "Ok, well, they're 
obviously not as mature. However, they approach things with far fewer preconceptions and are generally a little more eager to jump into things." Having students who are willing to try something new, it seems, allows the teacher to have fun as well introducing the students to many different activities throughout the year.

Three participants $(1,2, \& 7)$ simply state a fondness for young children. When asked what he likes about teaching elementary age children, Participant 2 responded:

"Uh, I like that they love you! [laughter] You know, I always like the little kids. I worked at 4-H camp when I was growing up, as a teenager. I just was always drawn to the little ones. I don't really know why. I guess because I feel, I just feel like I relate to them because I'm a big kid. [laughter]"

Most all seemed to have a playful personality, often joking and laughing during the interviews. Individuals with this type of personality often work with children in one way or another.

\section{THEME SEVEN—VALUE OF ENSEMBLES}

Many of the teachers' most memorable experiences were seasonal programs and ensemble performances rather than general music classroom activities. Teachers 1, 4, and 6, specifically, mentioned Christmas performances as their most memorable experiences as music educators. These programs often included dramatic elements or full-stage musicals. The students involved in these productions included more than one grade level, and at times, every student in the school was part of a single school-wide performance. Participant 4 describes a concert that included her choir, Orff ensemble, and classes from every grade level: 
"I think it was the collaboration that I did that ended in a performance. Working with our G.A.T.E. [Gifted and Talented Education] teacher." . . " "and our art teacher" . . But, we put a performance together from a book and it was so Orffbased. It all just came together and the kids made up dances and they created instrument pieces and then we had narration and, um, songs. It was for a Christmas performance. Actually putting everything I've learned into action, taking what they've learned and using that, making it more of what they've learned in here instead of just putting on a performance to put on a performance. That was the most SATISFYING experience I can think of. I really enjoyed it. People still talk about it, 'Remember when you did the Christmas ...' Whatever that book was!"

After planning and organizing such a big event, it is natural to feel gratified when the concert is a success. This teacher called attention to the fact that the children are able to demonstrate what they have learned in an active and authentic way. Many other teachers $(2,3,6,7, \& 8)$ also described their performances as a vehicle to showcase what children had learned in the classroom. Some teachers will label these as "informances." Participant 1 explains:

"So, when you get to hear them sing or watch them folk dance without you on the stage, you think, 'I taught them that and these are . . . they get to demonstrate on their own how they are successful."

Even though these programs require a great deal of planning and preparation, the participants spoke about them very positively. Most of these productions were described as examples of their most memorable experiences teaching elementary music. Successful student performances often provide validation of one's work or serve as an assessment of achievement. 


\section{CHAPTER FIVE \\ DISCUSSION}

\section{INTRODUCTION}

The purpose of this qualitative study was to examine the experiences of current general music teachers to determine what most influenced them to pursue their current positions in elementary teaching. The three central questions of this project were:

1) What experiences do they describe from their childhood or during their collegiate career that influenced their desire to teach music at the elementary level?

2) What experiences as an elementary music educator have influenced their decision to stay or leave the elementary level?

3) How do these experiences affect a person's satisfaction as an elementary music teacher?

Several studies have been conducted researching the training of pre-service elementary music teachers, professional identity of elementary music teachers, and individual teaching experiences. This study aimed to fill a gap in the research exploring many other experiences during grade school or outside of college that may have influenced their preference to work with children. It also investigated teaching experiences that influence their decision to continue teaching at the elementary level.

\section{IMPLICATIONS}

The results of the study suggest that music teachers may have common paths to becoming elementary music teachers. Participants in this study shared a number of common experiences that influenced their decisions to pursue teaching at the elementary 
level: Childhood Enjoyment, Pre-service Preference, Post-College Preference, Value of Field Experience, Creative Opportunities, Interest in Young Learners, and Value of Ensembles.

\section{RECOMMENDATIONS}

These themes echo general reflections of previous studies, but suggest that new music educators are similar in their career path to any elementary teacher. The following are recommendations to education students, collegiate music education professors, and current elementary music teachers.

\section{Recommendation I}

Music education students should be open-minded about teaching elementary students. Both the reviewed literature and the results of this study show that most music education majors begin their college career with a goal to become an ensemble director at the secondary level (Bertke, 2008; Gordon, 1999; \& Hellman, 2008). Students develop an interest for elementary music during their elementary general methods course and more often during student teaching (Gordon, 1999 \& Campbell, 1999). This qualitative study confirms both of these trends. Half of the teachers interviewed in this study stated that their decision to pursue elementary teaching changed during their methods course. The other half indicated their decision was made after teaching in an elementary school. None of the participants entered college with a desire to teach elementary.

Music education students should willingly participate in field experience at the elementary level and not dismiss the option of teaching elementary too early in their 
career. There are few teaching positions at the secondary level and more people competing for these jobs. Some teachers will have to accept a position at an elementary school even though they would prefer a position at the secondary level. They will feel more prepared for a successful first year if they have had adequate field experience working with elementary children and applied themselves during their teacher training courses and student teaching.

\section{Recommendation 2}

Music education professors should include many opportunities for field experience. As research suggests (Campbell, 1999 \& Gordon, 1999), pre-service experiences are essential for music education students. Such experiences in the field allow a more realistic environment and students may feel more prepared as they enter the teaching field. Many participants in this study indicated that their most valuable moments during their college years were while observing or assisting in the schools. Most thought there was not enough off-campus experience working with children. Elementary methods courses often include peer teaching, but teaching young children is very different than teaching fellow classmates. Students may develop a more realistic impression of their own teaching skills and feel more prepared for student teaching and entering the job market if they have observed classes and have pre-service field experiences as part of their teacher training. 


\section{Recommendation 3}

Current elementary music teachers should try to provide memorable musical experiences for their students. Nearly all the participants in this study voiced negative moments as elementary music students in their own childhood. When they tried to recall positive experiences as young musicians, a few could not remember anything.

Most positive memories appear to be in ensembles at the secondary level. Research shows that most education students are influenced by a former teacher (Valadez, 1999) and often high school ensemble directors have served as these role models (Bertke, 2008; Lautzenheiser, 2001; "Recruiting for the Profession," 2000; \& Wilcox, 2004). This may be linked to the trend that most music education students begin college with the intent to become ensemble directors at the secondary level.

When recalling their experiences as students in elementary general music, nearly all the participants in this study described a routine that included "singing out of books" every day and passive music-making. To provide a memorable and engaging experience, teachers should include a variety of active-learning activities as a central strategy to developing their music lessons. They should reflect on their curriculum and evaluate their teaching approach to include discovery learning experiences while teaching core content as required by the state or district. Use of the Kodály and Orff approaches appeared to be part of this revelation among the teachers in this study.

If children have positive experiences in elementary school they may pursue music as a performer but certainly will have a better chance to develop a lifelong appreciation for music. Elementary music teachers are often the first chance children have to make music themselves; their experiences at elementary school can leave life-long positive or 
negative impressions. Teachers must have "a passion for little people;" providing a welcoming environment with a variety of creative activities will ensure positive memories of elementary music-making. After many years of providing this positive foundation, one future music educator may declare their interest in becoming an elementary music teacher.

The participants in this study shared many common experiences that influenced their preference to teach at the elementary level. The above recommendations may foster positive experiences with elementary music that may influence others to pursue this field. Most of these suggestions can be easily implemented, to some degree. Music education degrees already have many requirements that reflect these recommendations. Teachers must make a concerted effort to continue to do more in these tasks and directions. College students may not have adequate time in their weekly course schedule to leave campus and visit an elementary school until their junior or senior year of college.

However, if possible, all these recommendations may directly influence a music teacher's decision to pursue teaching at any level, including teaching in the P-6 grades.

\section{FUTURE RESEARCH}

Based on this project, there are several areas for future study. Although results of this study can be useful, more research should be done with a larger sample. Also, all the participants in this study were primarily instrumentalists, specifically woodwind and brass. In future studies, the sample should include teachers with a variety of backgrounds including vocalists, pianists, string players, and percussionists. Students in choir or 
orchestra may have very different experiences than those in band. There may be a difference in findings if the sample includes a wider variety of backgrounds.

This qualitative study could also be conducted in multiple locations across the state, or the country. This study sampled music teachers who are currently teaching in rural counties surrounding a major metropolitan area. By conducting research in multiple settings, research could determine if varying regions have any affect on the responses.

Research shows a dominance of females in the field of elementary music education. Although the sample of this study included both male and female teachers, the issue of gender was never mentioned by the participants. Perhaps future studies could aim to examine personal experiences of elementary music teachers based on gender.

There has been little evidence of research exploring elementary music teachers' past experiences as students in elementary music. Most of the participants in this study described music class as boring and sedentary involving a routine of singing from a textbook. Only one participant had a positive music experience in elementary school using Orff techniques. It would be interesting to compare students from these different backgrounds to determine the effects of Orff or Kodaly on the motivation of new teachers. If students have positive feelings about their elementary music experiences, will they be inspired to pursue music in the future?

Also, while the focus of this study was to assess the motivations of these teachers, focusing on teachers who have taken Orff or Kodály teacher training courses might prove to be useful. Such an investigation might help to determine the value of such training earlier in a teacher's training. 


\section{REFERENCES}

Bernard, R. J. (2004). Striking a chord: Elementary general music teachers' expressions of their identities as musician-teachers. Ed.D. dissertation, Harvard University, United States -- Massachusetts. Retrieved April 10, 2010, from Dissertations \& Theses: Full Text. (Publication No. AAT 3134467).

Bernard, R. (2005). Making music, making selves: A call for reframing music teacher education. Action, Criticism, and Theory for Music Education 4(2). Retrieved from http://act.maydaygroup.org/articles/Bernard4_2.pdf

Bernard, R. (2009). Uncovering pre-service music teachers' assumptions of teaching, learning, and music. Music Education Research, 11(1), 111-124.

Bertke, R. P. (2008). Influences on first-year music education majors' degree choice, perception of achievements, and motivation: a qualitative study. Unpublished masters thesis, University of Louisville School of Music, Louisville, KY.

Bruner, J. S. (1960). The process of education. London: Oxford University Press.

Campbell, M. R. (1999). Learning to teach music: A collaborative ethnography. Bulletin of the Council for Research in Music Education, 139(Winter 1999), 12-36.

Choksy, L. (1999). The Kodály method I: Comprehensive music education. $\left(3^{\text {rd }} \mathrm{ed}.\right)$ Upper Saddle River, NJ: Prentice-Hall, Inc.

Creswell, J. W. (2005). Educational research: Planning, conducting, and evaluating quantitative and qualitative research. $\left(2^{\text {nd }}\right.$ ed.) Upper Saddle River, NJ: Person Education, Inc.

Creswell, J. W. (2007). Qualitative inquiry \& research design: Choosing among five approaches. ( $2^{\text {nd }}$ ed.) Thousand Oaks, CA: Sage Publications, Inc.

Gordon, D. G. (1999). The metamorphosis of a beginning music educator. Teaching Music, 7(3), 38-41.

Hellman, D. (2008). Do music education majors intend to teach music?: An exploratory survey. Update: Applications of Research in Music Education, 27(1), 65-70. 
Hoffer, C. R. (1993). Introduction to music education. Belmont, CA: Wadsworth Publishing Company.

Johnston, J., McKeown, E., \& McEwen, A. (1999). Choosing primary teaching as a career: The perspectives of males and females in training. Journal of Education for Teaching, 25(1), 55-64.

Krueger, P. J. (1999). New music teachers speak out on mentoring. Journal of Music Teacher Education, 8(7), 7-13.

Lautzenheiser, T. (2001). WANTED: Music teachers for the present and future. Teaching Music, 9(3), 36-39.

Recruiting for the profession. Teaching Music. 8(2), 24-31.

Roulston, K. \& M. Mills. (2000). Male teacher in feminised teaching areas: Marching to the beat of the men's movement drums? Oxford Review of Education, 26(2), 22137.

Shindler, J. V. (1998). Who gets into teaching? Cognitive style as a variable in predicting teaching as a career choice. Retrieved from ERIC database on May 24, 2010. (ERIC Document Reproduction Service No. ED423219)

Seidman, I. (2006). Interviewing as qualitative research: A guide for researchers in education and the social sciences. $\left(2^{\text {nd }}\right.$ ed.) New York: Teachers College Press.

Steen, A. (1992). Exploring Orff: A teacher's guide. New York: Schott Music Corporation.

Valadez, J. J. P. (1998). Factors influencing the decision to pursue an elementary education degree as identified by female student teachers in selected Texas private universities. Ph.D. dissertation, Texas A\&M University, United States -Texas. Retrieved May 24, 2010, from Dissertations \& Theses: Full Text. (Publication No. AAT 9903218).

Wilcox, E. (2003). A Mid-Career Teacher's Juggling Act. Teaching Music, 10(4), 28-33.

Wilcox, E. (2004). More than a living: Teaching in an urban school. Teaching Music, 1I(4), 24-28.

Wilcox, E. (2005). It all depends on you: A rural music educator who won't quit. Teaching Music, 12(4), 26-31. 


\section{APPENDIX A: INTERVIEW PROTCOL}

Time of Interview:

Date:

Place:

Interviewer:

Interviewee:

Position of Interviewee:

The purpose of this study is to examine the experiences of current general music teachers to determine what most influenced them to pursue elementary teaching.

I will be interviewing current elementary music teachers in this school district.

This interview will be tape recorded so that I may listen back to the interview, but you will remain anonymous in the transcripts that will be reported in the research findings. I estimate that this interview will take about 30 minutes.

[Have interviewee read and sign the consent form.]

[Turn on tape recorder.]

\section{Questions:}

\section{Background Information:}

1) How long have you been a teacher?

2) Where did you get your teaching training? What is your official degree certification? (K-12, vocal, instrumental, general)

4) What was your major performing area? (vocal/instrumental)

5) How long have you been in this school?

6) Is this your first teaching position?

7) Have you taught at any secondary schools?

8) What grades and ensembles do you currently teach?

9) Do you teach anything other than music?

\section{Music Teacher Identity}

10) What attracted you to your current position?

11) What do you like about teaching elementary age children?

12) Do you have a preference for a particular age or grade level? Why do you suppose that is?

13) Do you feel that you are successful as an elementary music teacher? How so?

14) What kinds of activities do you most like doing with your children? Are these things you learned in college, workshops, remembered from childhood, or something else?

15) What is your most memorable experience as an elementary music teacher in the past few years?

16) When did you decide you wanted to teach elementary music?

17) Do you hope to continue teaching at the elementary level for an extended time? 


\section{Teacher Training Experiences}

18) Think back to your first year teaching. Did you feel like you were prepared to teach elementary music?

19) Are there things you wished you had learned before you started as an elementary music teacher that you did not learn in college? Where were the gaps?

20) What was the most valuable experience during your college training that helped prepare you to teach elementary music?

21) Do you think there were other experiences outside of college that have helped prepare you to teach elementary music?

\section{Professional Development, since college}

22) What have you done to learn more about teaching elementary music since your college days?

23) What do you currently do to improve your teaching and musicianship? (attend workshops, conferences)

24) Do you have a mentor, peer, or support group that you turn to for advice about teaching elementary music?

\section{Elementary Music Background}

25) Are there any musical experiences you had as a child that you are now sharing with your students?

26) How does your current elementary music classroom compare to your experiences when you were a student in elementary school?

\section{Summation}

27) Is there anything else you would like to share regarding your preference for elementary music that we have not yet discussed?

Thank you, again, for participating in this interview. I assure you that your responses will be kept confidential and used only for the purpose of this research project. If there is anything you think of after today that you would like to add, you may contact me by email and we will arrange a time to meet. 


\section{APPENDIX B: INTERVIEW TRANSCRIPTS}

\section{Transcript of Interview with Participant \#1}

Investigator: Question 1, how long have you been a teacher?

Participant \#1: This is my sixth year.

I: Ok, where did you get your teacher training and your degree?

P1: I went to Indiana University in Bloomington for my bachelors in music ed area. I did choral, general and instrumental.

I: Ok, and your masters?

P1: Not yet.

I: You're planning on working on that?

P1: Yes.

I: And your major performing area? Your degree was in all three?

P1: Choral, general, and band. There was no orchestra as a part of it. So I kind of did a double. So, my major instrument was piano. I also played piano, I mean oboe.

I: Ok, piano and oboe. How long have you been at this school?

P1: Uh, six months. This school year, I started in August.

I: Is this your first teaching position?

P1: No.

I: Have you taught at any secondary schools?

P1: I student taught at a high school, but not ever on my own.

I: Uh, what grades and ensembles to you currently teach at this school?

P1: I teach K-5 and I have choir and Orff Ensemble.

I: Ok, how often do you meet with the choir and Orff? 
P1: Choir is twice a week for 20 minutes and Orff is three times a week for 20 minutes.

I: Wow! That's a lot of rehearsal time. Um, do you teach anything other than music, like dance or drama or art?

P1: Um, I do teach a little bit of dance. Which is ... this year it's more my choice because I think a lot of it goes together, so ... And then ... I teach RTI. I do a reading intervention group for 40 minutes Monday through Thursday.

I: That's mandated by your principal?

P1: Yes.

I: What attracted you to your current position?

P1: It was full-time and a new building. Umm, and full-time music. I didn't have to teach anything else. Previously I taught half music and half art. Which art is not my specialty, so I was happy to have full-time music.

I: Yes! What do you like about teaching elementary age children?

P1: A lot of the experiences you give them are new for them. So, like exposing them, being able to be the one to expose them to lots of musical things--concepts, ideas, music can be fun! I feel that if I'm one of the first to get in there about music then I can mold them and make it interesting and hope that they'll pursue it.

I: Do you have a preference for a particular age or grade?

P1: Within elementary?

I: Yes, within elementary.

P1: It depends on the school year because ... there are always grades ... you know ... easier to deal with than others. [laughter]

I: So you don't lean towards a certain grade?

P1: Well, I think ... I like $3^{\text {rd }}$ grade, because I feel like its the middle of the ground where they're still innocent and you can do more of the child-like games but they're smart enough to really get the more advanced concepts.

I: Do you feel that you are successful as an elementary music teacher? 
P1: Yes, I do. Because I feel like the kids do have fun. They learn things. They can read music. They can clap rhythms. They can do what I'm asking them to do and I think the activities that I choose are worthwhile.

I: And the kids know that you expect them to learn and have fun at the same time?

P1: Yes.

I: What kinds of activities do you most like doing with your children? And are these things you learned in college, or workshops, or remembered from your childhood?

P1: Um, I most like games and folk dances because I think they're more complex and they require a few different skills to be working at the same time. To be successful at a folk dance, you have to be able to move your body, listen to the phrasing, listen to the caller, and have a greater understanding. Plus, it's fun! They love it, I love it. I learned . . . I guess I learned a lot of them in my elementary methods course in college and then I took all three of my Kodály levels. So I learned some then also. And then workshops also. I've attended a few specific to folk dances.

I: What is your most memorable experience as an elementary music teacher in the past few years?

P1: That's really hard! [laughter] Um, I guess pretty much performances because there's lots of practice and, and um . . .process that goes into a final result. So, when you get to hear them sing or watch them folk dance without you on the stage, you think, "I taught them that and these are ... they get to demonstrate on their own how they are successful."

I: How many performances do you usually plan a year?

P1: Um, two or so. December and sometime in spring.

I: And all of your ensembles perform at the same concert?

P1: Yes. .. It's varied at a few different schools. It also depends on the school.

I: Do you ever have kids that aren't in choir or Orff perform? Like a whole grade?

P1: Sometimes. . . so, at a different school last year, I did have every grade perform at some point, so some ... actually they all performed at Christmas. We had two different Christmas performances and that was for anybody in the grade level. All the third grade learned the same song, so when it was $3^{\text {rd }}$ grade time, any $3^{\text {rd }}$ grader that was there just went up on the stage and sang. And choir was a part of that also. Um, this year it's just been choir and Orff, but it will be all of $4^{\text {th }}$ grade because they're doing recorders.

I: Will they perform together, or individually or in small ensembles? 
P1: Uh, both. I'm not sure about recorders.

I: Ask in May right?

P1: [laughter] Yes. Choir and Orff we did songs on our own and then we did one song combined. So, I think it would be fun to combine all three of them. Um, and when I first taught in Texas, that principal REQUIRED that every grade have a performance. He, um ... so, there was more performances than two a year there, but we just . . . and that school was huge so we had, um, and there were 9 classes of $3^{\text {rd }}$ grade, for example. So we just had the third grade night and within the third grade I taught a few different classes different songs so we put it together that way.

I: This was a public school?

P1: Um hum.

I: When did you decide you wanted to teach elementary music?

P1: Oh, that's hard ... I think ... I think sometime in college. I . . probably junior year in college when I had elementary methods and I realized how much fun you could have with them and how . . . how much REAL music you really can do with them. I think I at first wasn't sure that you can make elementary music meaningful because my elementary music was very superficial, I feel like. So, but, when I learned, yeah, how much you can do with them, I thought, "Well, this could be interesting." So I think that was the first time I thought, "Oh, I could do this." And I still felt like I could high school too, so ... but as I grew my experiences and I helped out with the children's choir at IU, things like, I realized I liked it.

I: So when you first chose to be a music ed major, you thought you would teach high school?

P1: I wasn't sure. Um, also, that was why I was area. I did everything. 'Cause I thought, I could still picture myself doing marching band 'cause I did that for all of my high school and was drum major and thought, "Well, I could do the instrumental route." And then, um, and I actually thought of myself in a real small district where I did everything. Or a Catholic school or something where it was K-12 and they needed one person that could be the jack of all trades and I thought, "Oh I could do that!" [laughter] But, I'm glad I'm not doing that!

I: Do you hope to continue teaching at the elementary level for an extended time?

P1: Ah, yes! Um, I think, maybe throughout my entire career, eventually I might want to change levels just for variety, but for now, yes, five, ten years, yeah. I like what I'm doing. I feel like I get better at it as I go, so keep getting better at it. 
I: Think back to your first year teaching, did you feel like you were prepared to teach elementary music?

P1: Uh, yes, for the most part. I think I was definitely prepared to teach my content area. I think probably with anybody who's a new teacher, you have to get used to the other things that you can't practice when you're in a classroom full of college students. Like discipline, or just figuring out how to do PO's and how that process works, and interacting with other teachers. And you're the only music teacher, so fitting in to how everybody else kind of has a group they're with. Like here's the $3^{\text {rd }}$ grade teachers or classroom teachers. You're kind of different so...

I: Yeah.

P1: But as far as me and my classroom with the kids and doing music stuff, yes.

I: And interacting with the kids?

P1: Yes.

I: And teaching music you felt prepared?

P1: I did.

I: Mainly because of your college work?

P1: Yes, and Kodály, if you count that.

I: And Kodály. So you had Kodály ...

P1: It was in addition to; it wasn't part of my undergrad.

I: But you had it completed before your first teaching job?

P1: No, I had, um; I had two ... I think I had two levels before I started teaching.

I: Are there things you wished you had learned before you started as an elementary music teacher that you did not learn in college?

P1: Yeah, well ...

I: You kind of answered it a little bit, but not necessarily about music.

P1: Um, I guess, I mean, I like all three of the Kodály levels. So, had I had the third before, that would have been nice. I don't know. . . do you want more specifically about music? 'Cause I do wish there was a little bit more about, well, I guess that is music. They need a course for music teachers and something about how they fit into a school 
building, when you're the only music teacher. I don't know if that makes any sense. But, like, how I do RTI here. It's not my favorite and I don't like that, but I don't think it's appropriate for me to say, "I don't want to do that." You know what I mean? But I wish I had some guidance I guess for my higher ups.

\section{I: A support system while you're teaching?}

P1: Yeah ... yeah, I guess that's not really what you learn in college ... can we come back to this? [laughter]

I: Yeah, it's fine.

P1: It's true, though. No matter what you do, you need a support system in where you are.

I: What was the most valuable experience during your college training that helped prepare you to teach elementary music?

P1: Um, my elementary music methods course. We were exposed to Kodály, Orff, Dalcroze, lots of different methods. It was really hands on. We did a lot of demonstrating. We went into the schools and observed. We also observed our professor teach a class of elementary kids and then we had to go in and teach as pairs and also independently. Then we kind of picked apart all that and learned what we could do better.

I: Lots of in-school observations before student teaching?

P1: Yes!

I: Do you think there were other experiences outside of college that have helped prepare you to teach elementary music?

P1: Um, well, like when I helped out with IU children's choir. Its still part of IU, but that wasn't part of my college course work. Um, that definitely helped because they had an hour choir rehearsal which we were kind of assistants or accompanists and then they had a half an hour musicianship class. So I taught ... I got some experience actually teaching musicianship so,

I: Working with elementary aged children?

P1: Yes. So, I had mostly seven and eight year olds. The choir had that age group. They'd go and I got to try out some of the games and things we'd learned about. Uh, and also workshops.

I: Workshops?

P1: Um. . I guess that's been continuous. But going to the KOSA workshops. 


\section{I: During your undergrad?}

P1: Um ... yeah, you mean undergrad? I guess I didn't go to so many workshops in undergrad. [laughter] Sorry ...

I: No, that's fine! What have you done to learn more about teaching elementary music since your college days?

P1: Ok, so then, goes workshops! Yes!

I: You go to KOSA workshops?

P1: Yeah, not all of them, but some. And then KMEA. When I was in Texas, it was TMEA. Um, yeah, there it is huge! It's like 25,000 people! And they're ALL music teachers! It's crazy!

I: What do you currently do to improve your teaching and musicianship?

P1: Um, I attend concerts, Louisville Orchestra concerts. Which, that does help my musicianship. I'm applying for my masters, to start a masters. That's certainly improving. Um, I guess attending workshops, or PD other than music does help your teaching. Not necessarily your music teaching, but um, here we're doing the positive discipline.

I: Yeah, and that definitely affects your classroom and whether your lesson is successful.

P1: Exactly.

I: Do you have a mentor, peer, or support group that you turn to for advice with teaching elementary music?

P1: Um, yeah I still call some of my friends from college who are elementary (one's middle school) music teacher but we still bounce ideas off of each other or "Oh, I forget the song that we did that goes like this ... Do you remember?" And I think here in County when we get together once a month, the music teachers, that's at least helpful to hear what some other experiences are in the district.

I: Yes. Are there any musical experiences you had as a child that you are now sharing with your students?

P1: Um, my more memorable musical experiences were in middle and high school. I remember being in . . . um, all-state band, choir, um, some orchestras in Philadelphia. I lived right outside of Philly, so ... that's where I realized that music was kinda my thing. And then that now gets translated to what I teach because I feel like every kid should have the opportunity to see if music is THEIR thing. So, we may not be able to put them 
in all-state orchestra in $5^{\text {th }}$ grade. BUT, if they're intrigued and have had good experiences, they may go on to explore that.

I: So what was your elementary music like?

P1:Um, we watched a lot of movies like "Fiddler On the Roof" and "The King and I." And we sang a song about chocolate that I still remember, [singing: "Chocolate! Gimme Chocolate! da na na na na naaa na na na..."] with recordings. It was bad! And it was also, I remember some years music was in our classroom which wasn't a very good environment.

I: So there were space issues too?

P1: Yeah, and then we did get a room, a new room. But it was the art and the music room together, so ... it was bizarre too. I'd still like that actually.

I: So, do you find anything you do similar to things you experienced?

P1: I hope not because I didn't like it! [laughter]

I: So you try to be completely opposite?

P1: Well, um, I remember learning dynamics, piano and forte, and things like that in elementary school and I do expect $4^{\text {th }}$ and $5^{\text {th }}$ graders to know that. So, there are some basic concepts that are similar. But I guess I don't . . .

I: You don't teach it the same way?

P1: No, and now I'm trying to remember if we sat and did worksheets or how we even learned what piano and forte were. But I'm not really remembering very much.

I: Ok. How does your current, well, we kind of talked about this. How does your current elementary music classroom compare to your experiences when you were a student? I just asked you that. Ok. Is there anything else you would like to share that influenced your preference for elementary music?

P1: Um, yeah, I think ... when I . . part of my philosophy is that everybody should be exposed to music. And I think elementary school is now, unfortunately, the only time when a music teacher gets to see EVERY student. By the time they get to middle and high school, they have to choose often among other electives. So, do you want to go to basket weaving or art or technology, we had in my middle school, or music. So, I really believe that everybody should be exposed to it. So, I'm happy that I'm at an elementary because I DO get to see everybody. Does that make sense?

I: Yes 
P1: And it might be the last time that a music teacher $\ldots 5^{\text {th }}$ grade might be the last time that a student has some clear music education.

I: I agree. 


\section{Transcript of Interview with Participant \#2}

Investigator: So, how long have you been a teacher?

Participant \#2: This is my . . . thirteenth year.

I: And where did you get your teacher training and certification?

P2: My teacher training and certification was at the University of Louisville.

I: And your masters?

P2: Masters degree at the University of Louisville also.

I: And did you get a degree in music education $\mathrm{K}-12$ ?

P2: Yes.

I: choral?

P2: Instrumental emphasis. I was an instrumentalist.

I: Oh, you play saxophone right?

P2: Um hum ... used to.

I: Used to? Oh, you still now how to! [laughter] Um, and your major performing area, we just answered that.

P2: Its voice now.

I: Voice now?

P2: Yeah, it has been.

I: Yeah, I knew you were a singer, but your degree? You still did the instrumental?

P2: It's instrumental emphasis. Technically, if somebody needed to, they could hire you. You're certified for anything. But they want to know if they've got somebody else looking for the job, what their emphasis is.

I: So, when you started did you think you wanted to be a band director?

P2: You know? I didn't know. I just knew I wanted to teach and I thought music was going to be the way to do it. And I went through all of the training, you know all of your, all of your preparatory training is in secondary music. 


\section{I: Yes.}

P2: I discovered pretty early on that marching band wasn't really one of my favorite things. Although, I really enjoyed concert band.

I: Well, how long have you been at this school?

P2: This is my ... fifth year, sixth year? ... Sixth year.

I: And, so this is not your first teaching position?

P2: No, I taught seven years at Elementary.

I: So you've always been at an elementary level? You've never been at any secondary schools other than student teaching?

P2: Right.

I: Uh, what grades and ensembles do you currently teach?

P2: Kindergarten through fifth grade. I have a third through fifth grade chorus. And a fifth grade Orff ensemble. And band, up until this year. . . may bring it back next year.

I: In addition to Orff? Or would it replace?

P2: It would be in addition ... yeah, we'd probably have them all.

I: That's nice. Do you teaching anything other than music like dance, drama, or art?

P2: I do teach dance. Um, I do a little bit of drama, but mostly dance and music. We call my class "performing arts class."

I: Ok.

P2: Because we do dramatic presentations and we dance here, so we're calling it what it is.

I: What attracted you to your current position?

P2: Proximity really, to my wife's job that she had. Also, my family's a little closer here. We were just a little too far out.

I: What do you like about teaching elementary aged children? 
P2: Uh, I like that they love you! [laughter] You know, I always like the little kids. I worked at 4-H camp when I was growing up, as a teenager. I just was always drawn to the little ones. I don't really know why. I guess because I feel, I just feel like I relate to them because I'm a big kid. [laughter]

I: Do you have a preference for a particular age or grade?

P2: Uh ... primary is what I liked more. After having taught for as long as I have, I don't really have a preference anymore.

I: Ok.

P2: I actually like the older ones, so we can do more performing ... I guess that would be the answer!

I: Do you feel that you are successful as an elementary music teacher?

P2: Yes, I feel I'm successful.

I: What kinds of activities do you most like doing with your children? And are these things you learned in college, workshops, remembered from your childhood, or something else?

P2: Um, what I like, MOST like, doing is playing music. Instrumental music.

I: Uh huh.

P2: Maybe that's because most of my training was instrumental or just because I like the fact that it is easy to do for the kids. They can get right in there and make music. Singing, I like doing that. But mostly I think I like playing the instruments.

I: What is your most memorable experience as an elementary music teacher the past few years?

P2: ... Well, that's a hard one ... um ... Well, last year after trying band for five years, I actually had a pretty good band. They really could play very well. And this year, I think every year's a better year. I mean, every year that I get better, the kids get better. You know more. So I think THIS year, this whole year! I think more my fourth and fifth grade because my fourth graders are reading more off the staff and they're just able to play so much more than my kids did last year. I wouldn't say I had ONE memorable experience. That's a tough question.

I: Ok, When did you decide you wanted to teach elementary music?

P2: Um, I . . elementary music? 
I: Yes.

P2: About my third ... I was just about one or two semesters away from finishing college ... and I took my elementary methods class and realized that was for me.

I: Ok. So that was your undergrad?

P2: Uh huh.

I: Do you hope to continue teaching at the elementary level for an extended time?

P2: Absolutely.

I: Until retirement?

P2: Perhaps ... I don't know what the future holds, but I would like to.

I: Think back to your first year teaching. Did you feel like you were prepared to teach elementary music?

P2: No... No.

I: How so?

P2: Um, well, because there's only one class really that's required and there's nothing else offered ... At the time there wasn't. And it was a good course.

I: So what did you do?

P2: I just took Orff classes and workshops, and watched other people as much as I could. But it was mainly going to workshops and learning about it myself.

I: So, what things do you wish you had learned before you started teaching that you didn't learn in college? Where were their gaps in your college training?

P2: Well, I think the curriculum for sure. What to teach and the order to teach it.

I: The scope and sequence?

P2: Yeah, the scope and sequence. It would have been nice to have more than one semester to get it all in.

I: They just need more courses specific for elementary?

P2: Yes. 
I: What was the most valuable experience during your college training that helped prepare you for elementary music?

P2: My elementary methods course.

I: Just the one class?

P2: Yep [laughter]

I: Do you think there were any other experiences outside of college that have helped prepare you to teach elementary music?

P2: Oh, yes! Like I said before, Orff workshops, Kodály, all the different workshops.

I: Are you trained in Kodály?

P2: I'm not trained in Kodály, but just going to different things with, what's his name? David Frego. Just going to those workshops.

I: And you have your Orff certification?

P2: Level 2.

I: Up to level 2? Ok, what have you done since your college days to learn more about teaching elementary music? Well, obviously you've done the Orff after college and workshops. Is there anything else?

P2: Well, I studied voice, which I didn't do in my undergrad. I studied that in my masters program. And so that helped me in the vocal area.

I: How many years did you wait until you started your masters?

P2: About three, four, probably four years. Almost too long, too late. Barely got those 15 hours.

I: What do you currently do to improve your teaching and musicianship?

P2: To improve it?

I: Um hum.

P2: Well, I read. I watch videos on occasion. I go to KMEA.

I: Do you have a mentor, peer, or support group that you turn to for advice about teaching elementary music? 
P2: Not really, just when we meet,

County teacher meet. We get to talk a little bit. I talked with teaching. It's just, "how's things going?" some. We don't talk so much about what we're

I: Are there any musical experiences you had as a child that you are now sharing with your students?

P2: Uh ... you know, I've never really though about that ... I guess if I ... not that I know of. Just that I sing, I mean I've always sang.

I: How does your current elementary music classroom compare to your experiences you had when you were a child?

P2: In elementary school, we had . . . the music teacher came around on a cart with books and we sang.

I: That's all you did?

P2: That was it. Yeah, well, she had a choir for maybe $5^{\text {th }}$ and $6^{\text {th }}$ grade, maybe $4^{\text {th }}$ through $5^{\text {th }}$ grade. I sang in choir. And I was in the band of course in elementary school.

I: No instruments or dancing?

P2: You know, I just don't think we did.

I: If you don't remember it, it wasn't that important anyway right?

P2: Right, it was just singing. Which is fine, I guess it's just the way they did it back then.

I: Are there certain song you remember singing that you use with your kids now?

P2: Now? Well, a lot of them are in those texts, those music text books. I come across them sometimes and use them. And some of the resources I have like that "Just Five Pentatonic Songs" has got a lot of them.

I: Just folk songs?

P2: Yeah, just folk songs that I remember. I've got a ton of books, but a lot of those are in those text book series.

I: Ok. Is there anything else you would like to share regarding your preference for elementary music that we have not yet discussed?

P2: Uh, well. I guess, mainly it's that my training was all in instrumental, in band. And I never really ever had a desire to teach band. I liked, you know, the concert band part of it, 
but I never felt drawn to marching band, which is what you have to do. And well, I wasn't trained in choral and I'm not a great pianist. You know, it was really just an obvious choice, but it was pretty much a done deal when I took that elementary methods class. I said that's where I'm going, you know? Does that answer your question?

I: Yes, thank you. 


\section{Transcript of Interview with Participant \#3}

Investigator: How long have you been a teacher?

Participant \#3: Well I've been at County for two years before that. So, ten years. for eight years and I was in

I: Ok.

P3: I took a long sabbatical when my kids were little.

I: Oh, yeah. I wish I could. Where did you get your teacher training and certification?

P3: I got it at Eastern Kentucky.

I: Ok, your undergrad and masters?

P3: Uh huh, I got them both there.

I: Did you do two separate programs, or was it like an MAT program?

P3: No, I got my bachelors in music ed, and I guess, well, about ten years ago, I went back and got my $5^{\text {th }}$ year degree. Yeah, I didn't want to have to do the orals and all that.

I: And what was your major performing area?

P3: I was instrumental. I did a double reed major, oboe and bassoon.

I: Ok. And you said you've been at for eight years?

P3: Uh huh.

I: Ok, and this wasn't your first teaching position. You said that you taught in County.

P3: Yes, two years at County before that.

I: And have you ever taught at any secondary schools?

P3: I did. County was actually, a very tiny little school and it was K-12. So, I taught everything.

I: Oh yeah? And you had ensembles? 
P3: I did. I had choir and I had band. You know, I don't think the little school is even open anymore. It was called . I think they closed it down, but yeah, I did

it all.

I: Ok, what grades and ensembles do you currently teach?

P3: Well, right now I'm just K-5. And it's just band.

I: You have band? How often do they meet?

P3: Twice a week.

I: For half an hour or so?

P3: Forty-five minutes.

I: Do you teach anything other than music like dance, or drama, or art?

P3: Um, well we do a dance unit. I do it once a year with the PE teacher.

I: Is that something you choose to do or has the principal requested it?

P3: No, we choose to do it. We did it for two weeks and the kids really enjoy it so we went ahead and expanded it and we did it three weeks.

I: What attracted you to your current position?

P3: Oh, well, that's a little tricky. I had always said I would never teach elementary music. A job came open and I applied and I was fortunate enough to get it. And after the first little adjustment period, I found that a really, really enjoy elementary music. It was a matter of, the job came open and I wanted to go back to work was really the reason I applied. But I really like elementary music. I think, at this point, I wouldn't teach anything but elementary.

\section{I: Really?}

P3: Yeah, I really enjoy it. I didn't think I would, because I'd always enjoyed the older kids more. But I really like my little ones.

I: Yeah? What do you like specifically about teaching elementary aged children?

P3: I think I was surprised with my first job in County, I was the first music teacher they had ever had. There was no material. It was pretty much, you just grope your way along. And I don't think that was a very fair accounting of elementary music. Really, of any of it! But the program here at was already established. I've got materials, I've got instruments, I've got books. And I was really surprised with the little 
ones at how much they can learn. I guess I had always kind of thought it was just providing a break for the other teachers. But I found that was really not the case. Like, my first graders can all read all their notes now. But, I was really, really surprised at how much they CAN learn and how excited they get.

I: Yes, their excitement is really nice.

P3: Oh, yeah, they get so excited! They LOVE the Orff instruments and we're getting ready to start recorder and they're just eat up with recorder. The other teachers are not, but the kids are.

I: Do you have a preference for a particular age or grade level?

P3: In elementary?

I: Uh huh.

P3: I like the $4^{\text {th }}$ and $5^{\text {th }}$ graders. I do like the older ones. It just seems like you can get a little more in depth with them. I like the ensembles. The little ones can play, but the older ones you can put them on parts and I do like the older ones better.

I: Ok. Do you feel that you are successful as an elementary music teacher?

P3: Um, I think I am. I think I could always find ways to be better, but yeah, I think I am. Out of $965^{\text {th }}$ graders, we've got 50 of them in band. And the kids ... the kids DO learn. And I've not seen anyone cry not wanting to come down the hall! I think we do pretty well out there.

I: Ok, what kind of activities do you most like doing with your children?

P3: Oh, I like the performance. I like to get the instruments out and play the instruments. That's my favorite thing to do.

I: Do you use songs you learned in college or workshops or ...

P3: Um, I've got a few that I drug out from college. It's been a long time since I went to college, but ... There's a few things I got from KMEA. All in all, I think it's just an accumulation of things I got from different places. My daughter teaches up in material. County. She'll send me things. We send things back and forth. We trade

I: What is your most memorable experience as an elementary music teacher in the past few years?

P3: Ok, it was a band student, and she was playing flute ... and she really needed to be successful. It was one of those things. You know, sometimes music is the only thing they 
can be successful in. So, she was playing flute, and it wasn't going well. She came to school one day and she cried because she wanted to quit band. After talking to her, it was because she was not being successful on her flute. So I talked her into not quitting, "Let's switch over to clarinet and see what happens." And she just fell in love with it. She did so well and it really helped her self esteem.

\section{I: Oh, great!}

P3: Yeah, you know, you don't have a lot of those. But that made me feel SO good that she did stay. And though she's never going to set the world on fire, she did stay and she ended up being able to help some of the others. She's just so sweet, you know, one of those sweet children that never causes a problem and she NEEDED to be successful. That just made me feel so good that she was able to.

I: You kind of answered the next question a little bit. But, when did you decide you wanted to teach elementary music? You said it was after you got the job at ?

P3: Yeah! [laughter] Yeah, it was the job that came open. And I almost didn't apply for it because I just felt more comfortable with older kids. But, my children all went to and I just really loved the school. I thought, "Well . . . I'll try." I think as much as anything it was a little apprehension and not really knowing what to do with them-not being sure that I could relate to little bitty ones because I ALWAYS preferred the older kids. I always liked middle schoolers. I think as much as anything it was just apprehension, thinking maybe I can't do that.

I: Do you think it was during that first year teaching at you decided you like it better?

P3: Oh, Yeah! Yeah, once I got into it and really kinda ... the first little bit of it was kind of nerve racking because I didn't really know ... there again, you're just kind of groping your way along. But after a short time, I was just sure that it was what I needed to do.

I: Ok, good! You said that you would like to do this for the rest of your life. The next question was, "Do you hope to continue teaching at the elementary level for an extended time?"

P3: Yes! Yes! I wouldn't want to go any place else.

I: So this is it? Until retirement?

P3: Yes, I love to do this. You know, it's a little harder as you get a little older you 'cause you get up and down in the floor a lot.

I: Yeah, well that was harder for me because I was pregnant too! 
P3: Oh, I'm sure! I'm sure. I'm sure. Every now and then I'll kind of laugh. You know, my little daughter will say something, and she's just 27. I'll laugh at her and then say, "Well, wait until you're in your fifties. We'll see how well YOU can get down in the floor can crawl around and be a cat!" We'll just kinda laugh. But I do love it. I think it's um ... pretty physical. You do have to ...

I: You have to be actively involved.

P3: You do it with them! If they're dancing, you're dancing! If they're doing it, you're doing it! And it's really cool. I just really love it. But, it's a lot harder than it used to be.

I: Yes. Well, your first year at the elementary school, do you feel like you were prepared? I mean, once you had the books and the instruments, do think you were prepared to teach elementary?

P3: Yeah, I think so.

I: Are there any things you wished you had learned in college before you started teaching at the elementary level?

P3: Yeah! Um, you're younger. You may already know this. But, when I went to school, I think it would have been wonderful had we been taught guitar.

I: Oh yeah?

P3: And we weren't. I was an oboe/bassoon major, so I played piano, but not as well some people do. And I think that ... um ... was a music major too. We were talking about it, and he plays trombone. It's like we should ... if you need to get a degree, you should take piano every year. You need to be GOOD on piano. You know, I play with my kids, and I play for them. And basically what I'm doing is playing right hand chording in the left hand. Um, my comfort level is not really good on piano. I think we should have had more piano and I would have loved to have learned guitar. If I weren't more ornery I could teach myself how, but I think a guitar class would be really good for elementary music.

I: So, mainly things to improve your musicianship to accompany the kids?

P3: Right, because you specialize ... well, what was your specialty?

I: Trumpet.

P3: Ok, so you pretty much specialized on trumpet didn't you?

I: Yeah. 
P3: Yeah, well, I was oboe/bassoon and we got everything else, but not to a GREAT degree. We had vocal class, but not very many. My piano class I had two years, no two semesters! We probably had two semesters of piano. And that's just not enough. It's hard to go on, and even trying to play now ... you've got other things to do too. To get in to practice and to play, there's just not really any time to do it. So ... well, yeah ... .

I: So what was the most valuable experience during your college training that helped prepare you to teach elementary music?

P3: Oh, gees, that goes back a long ways! [laughter] Well, it wasn't any of those dreadful education classes! Those were terrible! We got to go over a few times at model labs which was right there on campus and just kind of hang out with kids and teachers. Just watching the teachers interact with the kids, with the students. It really kind of opens you up what teaching you're going to do. 'Cause you really don't get that in the classroom. You go through all the methods, but once you get into the classroom and see the teachers interact with the kids, that's what it needs to be.

I: In a music classroom?

P3: Uh huh.

I: Ok.

P3: We got to go for elementary, we went to middle, we went to high school. We got to go kind of shadow and hang out with them a few days.

I: Your entire four years in undergrad?

P3: Um, that started my junior year.

I: Atleast before student teaching?

P3: Yeah, yeah, before student teaching. And I know now they get in there ... I've got a son that is student teaching right now and I think he got into the classroom (if I'm not mistaken) I think by the end of his freshman year. I think they got into the classroom just to shadow.

I: Um hum, that's nice.

P3: Yeah, and that kind of keeps your eyes open at what you're doing. So, that was good for me.

I: Do you think there were any other experiences outside of college that have helped prepare you to teach elementary music? 
P3: Hmm ... I can't really think of any. I guess student teaching, but that's all part of college. Um, no not really.

I: You never were in charge of child groups at church or anything?

P3: Oh, like bible school? I did bible school and things like that.

I: Ok. What have you done since college to learn more about teaching elementary music?

P3: Um ... a lot of times, it's just talking to other teachers. Um ... people who have done it longer than I have, that can give me insight and put me in the right direction. That's mainly what I've done.

I: You said you attend conferences and workshops?

P3: Right, right $\ldots$ but I think the most valuable experience is just talking to other teachers.

I: Yeah.

P3: Yeah, that was the best thing for me, especially that first year. You're a little nervous anyway and you want it to go well, but you're not REALLY sure what to do in certain situations. I found that talking to people who had been there awhile really gave me a lot of courage and a lot of advice.

I: Ok, what do you currently do to improve your musicianship?

P3: My teaching or my musicianship?

I: Well, either.

P3: Um, teaching? I try to ... look at ... well, we've had ... that one's hard.

Musicianship? I don't really do that much at all anymore. That's pretty much gone by the wayside. Teaching? I don't know. I just try to keep up with any new thing I can find. There again, I think I get THAT more from my daughter. I call her and ask her. And, you know, being with her, she'll tell me about things she's done. I just got some new drums last year that I didn't even know existed. Shape sounds? Have you ever seen those?

\section{I: I think I have, yes.}

P3: I'd never seen those and I went to a program that she was doing and they were so cool! All these different shapes of drums and the kids were just loving them! You know, I think it's just, if you're out and see programs, I can pick up hints and new things to do that way. 
I: Do you have a peer, mentor, or support group you turn to for advice? You said you talk to your daughter a lot.

P3: Yeah, I talk to my daughter a lot and I have a friend who used to teach at elementary, Mrs. . I don't know if you remember her or not.

I: No.

P3: Yeah, she maybe gone before you came. Um, we go to church together and she taught at elementary for, I think, thirty or some years, like 33 years or something like that. And she's really good to help. She help get started at and she's still a good "go-to" person.

I: Ok. Um, are there any musical experiences you had as a child that you are now sharing with your students?

P3: Hmm . . . let's see . . I had as a child? Well, we talked about, uh, we're getting ready to start recorder and we talked about, you know, being successful and what to do. And I would relate back to what it was like when I started. I got to start in third grade and we got to talk about how I felt and things like that. Same thing goes with band-_"You know, here's what I felt like and here's what I did and here's what you can do." Things like that.

I: Um, how does your current elementary music classroom compare to your experiences when you were a student in elementary school?

P3: Well, I didn't have music until fourth grade in elementary school. At all! So, I have very little memory of it honestly. I don't remember too much about my music class. I remember band, but I don't remember too much about my elementary music class 'cause we didn't have anything at all until about fourth grade. So . . this one's better. Our kids DO get to have it from kindergarten on.

I: When did you start band in school?

P3: Um, fourth grade.

I: But you had a separate music class too? Besides band?

P3: Yes, I did.

I: Ok.

P3: Yeah, we did the square dancing and NO reading. I remember it being more worksheets than anything. We didn't have any instruments. You know, the only time you got an instrument was when you were in band.

I: Oh, did you have a music room or did they come into your classroom? 
P3: No, we went to the music room. There wasn't anything there! [laughter]

\section{I: A big empty room?}

P3: There wasn't much to it. It was all hard wood floor.

I: Ok. I asked before about your conferences. Have you ever went to any Kodály or Orff training?

P3: No, I haven't.

I: Ok. Is there anything else you would like to share regarding your preference for elementary music that we have not yet discussed?

P3: Um ... no I don't think so. I'm just tickled to death that they're happy to come. And I'm just constantly surprised at how much they can learn. You only get them once a week for 45 minutes and they just AMAZE me! You know, you walk up to them singing, and they get it! And it doesn't go away! You know, we came back after Christmas and we were doing a little bit of review work. I'm just VERY amazed at how well they get it. All we get to get them is once a week. And sometimes programs come up and interruptions happen and you don't even get a class for a week or so.

I: Yes.

P3: It ... I would have never thought that they can get as much as they do. And that's probably just me not knowing what to think about elementary. I've been very impressed with how much they can grasp and what they can do. You know, your little kindergarteners, when they come in (mine anyway) don't have much of a sense of rhythm. Some of them don't. As you watch it develop and see them start to get it and it starts to dawn on them, it's really cool.

I: Yes. 


\section{Transcript of Interview with Participant \#4}

Investigator: How long have you been a teacher?

Participant \#4: I have been a full time teacher for ten years.

I: Ok, were you part-time at some point?

P4: No, for five years I subbed.

I: Ok. Where did you get your teacher training and your official degree certification?

P4: My undergrad was from UofL, Louisiville and I was instrumental, K-12 certified. And then my masters was at UK.

I: What was your major performing area? Vocal or instrumental? You said instrumental, but what was your primary instrument?

P4: Clarinet.

I: How long have you been at the school you currently teach?

P4: Ten years.

I: So, was this your first music position?

P4: Yes. Well, I had long-term maternity leave before, or something came up medically . .. I'd been in the school three months. But this was my first responsibility where it's MY job.

I: Right. Were you doing a maternity leave for a music teacher?

P4: Yes.

I: At an elementary school?

P4: Yes.

I: Have you taught any other secondary schools other than student teaching?

P4: Well, just for subbing. That was my main goal. I was not supposed to be elementary.

I: Ok, well, we'll get to that, I believe. What grades and ensembles do you currently teach? 
P4: I teach elementary general music from preschool up through fifth grade. I have a fifth grade band and a third, fourth, and fifth grade choir.

I: Do they all sing together, or do you have them separated?

P4: They all sing together.

I: Do you teach anything other than music like dance, drama, or art?

P4: Oh, dance.

I: Dance? Ok. You all actually have an art teacher at your school don't you?

P4: We do!

I: That's great. Alright, what attracted you to your current position?

P4: To be honest? A job opening. [laughter]

I: Ok, so you were just looking at anything at that point?

P4: Um, actually, I was looking at getting out of music all together. I had even signed up for subbing and I thought, "I don't want to be a band director. It's not going to be me." And a principal of the high school came (where I was working as a receptionist) and said, "You're good at this. You should go try the elementary job." I said, "Well, maybe I should" and I decided to get back into it.

I: Ok, what do you like about teaching elementary age children?

P4: EVERYTHING! [laughter] Everyday I come in and it's different. The personalities are all so different in one classroom. It's amazing how ready they are to do everything I ask them to do-sing, dance, play, play instruments, uh, work together, work by themselves. They're just SO open to ANY experience.

I: Ok, do you have a preference for a particular age or grade level?

P4: You know, I do. When I first started, it was the middle-aged because the little kids scared me. But now, somewhere around six or seven years, I'm starting to figure out the little kids. And I . . a anybody, I really don't have my favorite any more.

I: Ok, Do you feel that you are successful as an elementary music teacher?

P4: Partially ...

I: Ok, how so? 
P4: Um, I feel like some things they remember well. My instrumental background, I'm more redneck and that goes really well. Some of the things I do are more vocal based and I don't feel like I do well vocally as I do rhythmic and instrumentally.

I: So you think the kids don't grasp certain things because of your strengths and weaknesses?

P4: Correct, because most of my training was instrumental ... until Orff.

I: Ok, what kinds of activities do you most like doing with your children? And are these things you learned in college, workshops, remembered from your childhood, or something else?

P4: Um, what I like and what I use mostly is my Orff experiences where we take body percussion and words and things the kids give me and we transfer them to rhythm instruments and then to the barred instruments or to recorders. And that was things I learned from my masters classes and getting my Orff certification with my graduate studies. And so it was from my Orff training that I got that from.

I: How many years after you started teaching did you start your masters?

P4: Um, I started in 2000 . . 2003! Two years. No, three years!

I: What is your most memorable experience as an elementary music teacher in the past few years?

P4: Um, actually, you mean like during music class time?

I: Just as a music teacher. It could be with ensembles or in the classroom or whatever.

P4: You know, I think it was the collaboration that I did that ended in a performance. Working with our G.A.T.E. [Gifted and Talented Education] teacher. Are you familiar with G.A.T.E.?

I: Yes, I was in G.A.T.E.

P4: Well, there you go! Um, is doing that and our art teacher and um... well I guess it was just the three of us. But, we put a performance together from a book and it was so Orff-based. It all just came together and the kids made up dances and they created instrument pieces and then we had narration and, um, songs. It was for a Christmas performance. Actually putting everything I've learned into action, taking what they've learned and using that, making it more of what they've learned in here instead of just putting on a performance to put on a performance. That was the most SATISFYING experience I can think of. I really enjoyed it. People still talk about it, "Remember when you did the Christmas ..." Whatever that book was! 
I: How many kids did you have involved in that performance?

P4: Oh, it was the last time that ... second through fifth grade. My choir did all the songs, but they were joined by different grades. Each grade had a responsibility from stuff that they pulled out of music class to work on. It was a big deal.

I: That sounds ambitious, but I bet they loved it.

P4: Yeah! Oh, and kindergarten. I'm sorry.

I: When did you decide you wanted to teach elementary music?

P4: Um, after I had been here the first year, I decided to come back the second! I have to admit, I was going to be a high school band director. Oh, I wanted to be a middle school band director and an assistant to a high school because clarinet was my life! And after being here a year, and looking back on that year, I was amazed at how nice it was not to be going toward a performance and being able to teach. It was actually after I taught a year.

I: Do you hope to continue teaching at the elementary level for an extended time?

P4: I plan on being here twenty more years!

I: Ok, think back to your first year teaching. Do you feel like you were prepared to teach elementary music?

P4: Nope!

I: Had it been several years since you had your student teaching?

P4: Yes! It had been actually.

I: 'Cause you said there had been that break ... So then you decided to get your Orff levels soon after you started?

P4: Yes, a teacher had recommended Orff. The teacher, I took her place, had decided to be a stay-at-home mom and she said you REALLY should go take the Orff.

I: Are there things you wished you had learned before you started as an elementary music teacher that you did not learn in college?

P4: Um, yes ... But it wasn't that I didn't learn them, I didn't appreciate it. Since you're from UofL, I think you will know the name

I: Yes. 
P4: Because I think it was once semester, that's all we got 'cause we were instrumental, one semester of him teaching us . . . some of these theories, elementary music theories. I had him as a professor and I did not appreciate who he was and what he did. And I just knew I was going to teach band and I didn't need that.

I: So you didn't really pay attention to your elementary methods course?

P4: Exactly! I was opposed to it, but it was also just one semester.

I: So do you think that if you paid attention in that one semester it would have prepared you enough? Or do you think you still would have needed other training?

P4: I would have needed other training.

I: What was the most valuable experience during your college training that helped prepare you to teach elementary music?

P4: Undergrad or masters?

I: Either one.

P4: My undergrad DID NOT prepare me to teach elementary. I mean, like I said, part of it was my focus wasn't there. My masters classes, the best part was getting to participate in activities that I was going to be teaching my kids. Learning how to teach the process to get my kids to understand music.

I: Ok, do you think there were other experiences outside of college that have helped prepare you to teach elementary music?

P4: Um ... well, out of college. I guess, all of our KOSA workshops. Um, those are a big help. Going out and seeing presenters. Going to, actually, I mentioned going to people's schools. People who I consider Orff teachers or people who have had lots of experience. Observing teachers in actions and you know what to look for and see what they're doing. They explain things to you and that is a HUGE help! Getting to be right there in a classroom seeing what's going on. And my observations were mostly instrumental, we just did a few general music classes when I was in school.

I: Ok, what have you done to learn more about teaching elementary music since your college days?

P4: Um, in my masters classes, what I took there prepared me for this . . basically that's college. And then, my PD ... I base my professional development on what I need to be developmentally appropriate for these kids to make sure I understand them more. Um, I don't have kids myself and I think that's actually kind of a hindrance to teach elementary. You know, not understanding actually how they do it in little baby steps. So, it was all a 
whole new world. You know, any time I find a book about the child's mind or something like that, I try to read up on it because they're ... just ... they're foreign to me.

I: So you read a lot of literature?

P4: I do.

I: Ok, what do you currently do to improve your teaching and musicianship?

P4: Um, I KEEP attending sessions. AOSA, I go every two years. I usually go to KMEA every two years also. I try to split it up. And any type of KOSA thing I go to. And I've also done some Kodály. I've tried to venture out into Dalcroze and Kodály to try to get more ... well, to differentiate is what I was trying to get at.

I: Have you done any Kodály training at Morehead yet? They just started it recently.

P4: I haven't. I REALLY want to because I heard Joy Nelson was doing it and she is amazing.

I: Ok, do you have a mentor, peer, or support group that you turn to for advice about teaching elementary music? You mentioned the previous teacher had a few suggestions for you.

P4: Yes, I work closely with the elementary teachers here in the district. There's just four of us, of course, you know. And then with , we're emailing each other all the time, "Oh, this didn't work. How do you fix it?" So, just the peer group that I have. And also I collaborate closely with the teachers. If I'm not getting something through to a class, but I did the other classes, I go straight to their teacher and say, "What can I do?" I get out of my classroom and I go to the different grade teachers and talk to them about their kids.

I: Is it mostly questions about how they learn things, in what order? Or are they more discipline based?

P4: Yeah, more about how they act in class. Are they on grade level? If they don't have an IEP and I see that they're slower in here, I'll want to go to their teacher and find out how they do in class.

I: Ok, are there any other musical experiences you had as a child that you are now sharing with your students?

P4: Um ... I do get some songs, and I got this from professor too. Compile some songs that you did and I had to write them down and I just thought it was silly at the time. But now, I look back and I had a neighbor who was out there in the yard with me all the time. We'd play all these games that I don't think I would have ever learned if it weren't for her. She MIGHT be the reason that I'm doing this because she was signing 
with me all the time and do these songs ... um . . . the John Jacob Jingle-Heimer Schmidt song or duck-duck goose or anything like that ... she didn't have kids and she would get out there and do all this stuff with me!

I: Oh, so this was an older neighbor? It wasn't another child your age?

P4: Nope, it wasn't another child my age. [laughter] I was an only child and she was my mother's age. Exactly.

I: And she would do the games with you?

P4: Oh yeah!

I: Ok, how does your current elementary music classroom compare to your experiences when you were a student in elementary music class?

P4: [laughter] Um, my comparison is that there's four walls and a roof!

I: [laughter] Ok, well, describe your elementary music experience.

P4: Sure, we would walk in in line, we would pick up a book, we would sit in a chair, she would play a record, and we would leave. We would just sing.

I: You didn't have any instruments?

P4: $\mathrm{OH}, \mathrm{NO}$ !

I: No dancing?

P4: No.

$\mathrm{I}$ : So your classroom is completely opposite?

P4: Yes.

I: Ok, is there anything else you would like to share regarding your preference for elementary music that we have not yet discussed?

P4: Um . . . I think I covered it all. But, the reason that I want to stay at elementary instead of going back to the instrumental world. Um, you know, I still DO get to work the band camps and I get to play here in the summer for music theatre so I fulfill that. But, um, when I'm here I don't feel like I have to work toward a performance and I don't keep working on the same piece of music over and over. I REALLY appreciate being able to pick things out that are fun for the kids AND be able to teach them music. So, every day is just a play experience, with a purpose. Music teachers at UofL were looked down upon if they were general music teachers. It was like, "Well, why would you want to do that? 
Why don't you want to be a choral director or a band director?" I mean, that's what I saw in that. Well, I graduated in '93 and that's what it was like. And now I'm one and I even had a friend, at KMEA, I went to college with (well, he's not much of a friend now, I guess) say well, "Are you going to out of there soon? Are you going to get a high school job?" I said, "Oh, goodness no!" So, I think the mentality of the music world even needs to change and open up their minds too. We start these guys off. They have to start somewhere with their love for music and that's our job! The kids. 


\section{Transcript of Interview with Participant \#5}

Investigator: How long have you been a teacher?

Participant \#5: 10 years.

I: And where did you get your teacher training?

P5: Morehead State

I: And was your degree in instrumental, general, or vocal?

P5: Instrumental.

I: Ok, and what was your major performing area? Your primary instrument?

P5: French horn.

I: How long have you been at this school?

P5: Seven years.

I: Is this your first teaching position?

P5: No.

I: Have you taught at any secondary schools?

P5: High school and middle school.

I: One job had both?

P5: One job had a middle school and high school and one job had just middle school.

I: Ok, what grades and ensembles do you currently teach?

P5: Fourth and fifth grade choir and fourth and fifth grade Orff ensemble.

I: And the school is K-5? You don't teach preschool?

P5: Up until this past year I did.

I: Do you teach anything other than music like art, dance, or drama?

P5: Um, sometimes we dance, but I'm not required to teach it. 
I: What attracted you to your current position?

P5: [laughter] Just a lifelong love of music and working with younger children.

I: What do you like about teaching elementary aged children?

P5: They're always excited to try new things. They're not afraid to take risks ... They're just enjoyable to be around.

I: Do you have a preference for a particular age or grade level?

P5: Third grade because they ... they're at a point where you can do more and they still don't have the attitudes that are associated with fourth and fifth graders.

I: Ok, do you feel that you are successful as an elementary music teacher?

P5: [laughter] Yes, because I have a lot of students that go on to band in middle school. That tells me that they enjoyed my music class. Also, the test scores have continued to go up every year I have taught. Also, I feel that I'm always improving. I try to go to as many workshops as possible and try to go to KMEA every years.

I: What activities do you like doing most with your children?

P5: Um, Orff, anything Orff. Um, even though it's not core content, the composers. They really like to learn about the composers.

I: Ok, are most of these things you learned in college, or your childhood, or at workshops?

P5: Well, I learned the Orff stuff getting my Orff certification training. There was VERY LITTLE elementary in my college training.

I: Ok, What is your most memorable experience as an elementary music teacher in the past few years?

P5: Probably when I took my Orff ensemble to perform at the National Boards Conference. They worked really hard. I was very proud of them.

I: Was that when you received your National Board certification?

P5: No, it was a year before that.

I: When did you decide you wanted to teach elementary music?

P5: I got a job! [laughter] After my first year. I taught band at a high school and middle school but also had to teach beginning band to fifth graders. 
I: You had to drive to the elementary schools?

P5: Well, it was a K-12 school . . but I never thought I would like to teach elementary. I wanted to be a band director.

I: Do you hope to continue teaching at the elementary level for an extended time?

P5: Yes, but I'm working on my counseling degree.

I: So will you become a counselor soon?

P5: Perhaps, if the right job opens up. But I'm happy with what I'm doing.

I: Think back to your first year teaching. Did you feel like you were prepared to teach elementary music?

P5: No.

I: Are there things you wished you had learned before you started that you did not learn in college?

P5: Orff ... Also, general music versus instrumental. We got very little training in general music. Well, I had one class ... and MAYBE a few hours observing the field. But mainly everything was focused on instrumental.

I: Do you think you weren't prepared for the content or how to approach younger children?

P5: Well, just ... it would have been nice to know about resources for general music. I had TONS of resources for instrumental. And maybe ... how to break it down to their level.

I: Ok, what was the most valuable experience during your college training that helped prepare you to teach elementary music?

P5: I think, going to watch an elementary music class. Even though it wasn't much, we got to see how you interact with real students instead of your classmates pretending to be elementary students. So, the field experience.

I: Do you think there were other experiences outside of college that have helped prepare you to teach elementary music?

P5: All my Orff levels. 
I: Ok, what have you done to learn more about teaching elementary music since your college days?

P5: Again, my Orff levels ... and workshops, attending KMEA, and reading books and articles.

I: What do you currently do to improve your teaching and musicianship?

P5: I go to music specific professional developments and just ... try not to get in a rut. [laughter]

I: Ok, do you have a mentor, peer, or support group that you turn to for advice about teaching elementary music?

P5: Well, within the district, the elementary music teachers talk with each other and sometimes we get to meet during the monthly early release days ... I do have people who call me or email to ask questions.

I: Ok, so you serve as a mentor for other people?

P5: I guess. [laughter]

I: Are there any musical experiences you had as a child that you are now sharing with your students?

P5: My aunt taught me a lot of songs growing up, so I feel that ...

I: Folk songs?

P5: Yeah. She was an elementary school teacher, so she used singing a lot in her classroom. And then, I sang in church as a kid. I sang in choir. And then, I started band in grade school so I would talk to them about that.

I: So you would often share your experiences with them? You would tell them about things?

P5: Um hum.

I: Ok, how does you current elementary music classroom compare to your experiences when you were a student in elementary school?

P5: [laughter] Um, very different. I remember elementary school music was sit in a chair and they passed out a book, and we sang songs out of it. There were a few instruments, maybe some rattles or something, but that was pretty much it ... We did do a lot of dancing, like square dancing, I can remember. Other than that, it was pretty sedentary and just singing. 
I: Ok, is there anything else you would like to share regarding your preference for elementary music that we have not yet discussed?

P5: Um, just that I think it's a great environment to give to, um ... to get parents involved and show parents what their students can do. To show them that there are outlets for those kids who may or may not be into sports, things of that nature. It just gives them another option for their kids. 


\section{Transcript of Interview with Participant \#6}

Investigator: How long have you been a teacher?

Participant \#6: This is my second year.

I: Where did you get your teacher training and your official degree certification?

P6: My teacher training was completed at the University of Louisville in Louisville, KY. That is where my certificate is from.

I: Ok. Did you get a bachelors, or masters, or MAT?

P6: I have a bachelors in music and a masters in arts.

I: What was your major performing area, vocal or instrumental?

P6: Uh, actually, I was both. The university didn't have a program at that time that would accommodate both. I did private voice for two years, but my main area of focus was instrument.

I: Ok, and your main instrument?

P6: Oboe.

I: How long have you been at your current school?

P6: A year and a half.

I: So this is your first teaching position?

P6: Yes, the first time I've been let loose with children.

I: But you student taught at an elementary school as well?

P6: I did student teach at elementary school in County.

I: Have you ever taught at any secondary schools?

P6: Uh, I have not. I student taught at Middle School in County during the spring semester of my graduate year.

I: What grades and ensembles do you currently teach?

P6: Uh, currently I'm teaching K-8 general music at two parochial schools. 
I: Ok, do you have any ensembles?

P6: Yes, I have two children's choirs.

I: What grades are they?

P6: They are third and fourth graders at each building. Each school has a third and fourth grade combined choir.

I: Ok, do you teach anything other than music, like dance, drama, or art?

P6: Uh, all of those, I have the freedom in my curriculum to teach, but none of those are required of me except for general music. We have a separate art teacher.

I: Do you incorporate dance or drama into your classes?

P6: I use a lot of movement, especially with my younger elementary, in order to get them started moving and really feeling music. I also use drama with the older kids to give them the opportunity to explore, for example, Broadway musicals by having them create their own. I did a mini-Broadway musical unit with them and they actually had to come up with songs that they wanted to be a part of their Broadway musical and they actually had to write a skit and perform it along with that.

I: Ok, what attracted you to your current position?

P6: Well, the honesty is, that was the job that was available. But, one thing that did attract me to it was the opportunity to work with a wide range of kids. I actually liked starting the morning with the younger ones and finishing the day with the older students. You can see the progression that YOU start. What they know in kindergarten, you're looking long-term to see what they learn of over eight years.

I: What do you like about teaching elementary age children?

P6: I like the fact that they are so eager and excited about everything. If you say, "Hey kids! We're going to go shovel dirt today!" in a very excited voice, they're going to be excited about shoveling dirt! That makes your presentation very easy sometimes. "Alright kids, we're going to learn to sing la, sol, mi today and you're going to be awesome at it!" "Yeah, we're going to be awesome at it!" [student's reply]

I: Ok, do you have a preference for a particular age or grade level?

P6: Uh, I like the third grade through fifth grade the most. They're the ones who are starting to be able to take the information you're giving them and put it together and start ... They're going from the concrete to the abstract. They think and plan ahead and say, "Oh, this might happen if we do this musically." 
I: Ok, do you feel that you are successful as an elementary music teacher?

P6: Well, at the end of the year, nobody hated me. All the kids LOVED to come to music class. And when I did summative assessments, they were able to tell me what I asked them to learn. They can create music that were based on certain criteria, you know, very simple using Orff instruments. And I thought that was a great success for them.

I: What kinds of activities do you most like doing with your children?

P6: Well, like, rhythm and movement kind of games. Games where they're doing, maybe, echoing, rhythms on hand drums. Or games where they're creating rhythm patterns and sharing them with friends. We also really like to ... we, um ... I would put rhythms up on the Smart board and we would play the "Which one is Mrs. clapping?" game. I clap one of the different rhythms and they would have to tell me which one it was. That showed me that they were able to actually process things like tempo and time signature, and REALLY understanding what the different note values meant.

I: Are these activities things you learned in college or workshops?

P6: Uh, some of them were the result of , my music education professor in college. Some of them were accidents that you just kind of happened upon when you realize have five more minutes. You have to do something and you don't know what, so you make it up. And some of them were things I picked up student teaching with in County at elementary.

I: Um, what is your most memorable experience as an elementary music teacher in the past few years? I guess it would be the past year.

P6: Um, I would say, probably the Christmas program because one of the things that comes with elementary school that doesn't come with other grades is that, if you're the music teacher, you're in charge of the grand hoopla at Christmas. And the Christmas program at a parochial school is a HUGE deal. So, I think, being able to successfully put a K-8 program together where every student had a meaningful part of the presentation and something that was, you know, musically a good product along with the Christmas story begin told. After I finished both of those at my two different schools, I think that was probably the highlight of the year.

I: You taught two different schools that were K-8?

P6: Yes, I had two different schools that were K-8.

I: Ok, and EVERY student was expected to participate in those programs?

P6: EVERY student was expected to participate in all programs.

I: Uh, when did you decide that you wanted to teach elementary music? 
P6: Well, once again, the decision was made, kind of out of, what was available at the time. But, one of the reasons that I really like elementary was after I took the elementary methods class and my student teaching. ESPECIALLY, after student teaching I realized that this would not be a bad thing at all. I like the age group. I like the freedom. There are so many creative options when teaching elementary.

I: So you never though you would be able to teach elementary until you took the course in college, the methods course?

P6: The methods course in college gave me the hint, "Yes, this might be doable ..." After student teaching in my graduate year I said, "Yep, I can do this!"

I: Ok, do you hope to continue teaching at the elementary level for an extended time?

P6: I don't think the elementary for a LONG period of time will be where I will want to stay. I would eventually want to investigate teaching ensembles, um, in the middle-school range. I'm not a high school person at all.

I: Ok, think back to your first year teaching, which was last year. Did you feel like you were prepared to teach elementary music?

P6: Um, I feel that I was prepared to teach elementary music, but I don't think it was a direct result from the teacher prep program that I received at UofL. It was more a result of the intensive student teaching experience that is part of the fifth-year masters program.

I: Ok, where were the gaps? What did you wish you might have learned before you started teaching that you didn't learn in college?

P6: The major gap that I see transitioning from college preparation program into a regular classroom is the intensive focus on the core content for assessment. In especially, and even in __ County during the years I was student teaching, the combined curriculum document was coming out of its draft stage, that was 2006. You were REQUIRED to justify everything you do with that core content and I didn't even know what it was until I walked into County schools.

I: Yes, I know in college we focused more on the national standards but didn't address the state standards much.

P6: No, we did not address the state standards. I was very familiar with the national ones.

I: They're easy. They're short and sweet and to the point.

P6: Yep!

I: What was your most valuable experience during your college training that helped prepare you to teach elementary music? 
P6: Uh, once again, I have to go back to that intensive student teaching that the MAT program provides. I was able to not only see how the year started with the elementary program, I was able to see how HE used scope and sequence to build his curriculum and also for myself to get a good eight or nine weeks as the sole teacher in control to try out mine. I had the opportunity, the way their cycle was set up, to go back and do things again that hadn't worked the first time. So, being able to look at what I've done, evaluate how I've done, and then go back to try something different or improve on something that didn't work before. That was INCREDIBLY valuable.

I: So, how long were you student teaching at the elementary school level?

P6: The elementary school level was a full semester. I started in mid-August and I finished when UofL's semester finished in mid December.

I: Ok, and then did you also student teach at middle and high school both?

P6: Middle school was my only other placement. I did not student teach at a high school because I knew that just, that was not on the radar. They were able to get me a full middle school position.

I: Do you think there were other experiences outside of college that helped prepare you to teach elementary music?

P6: I do. I was very involved in my church during college and during my teacher preparation program. I was kind of the children's music person at my church. I had a choir that would have been, you know depending on the time you would have caught me, around 5-13 students all ranging from kindergarten through about sixth grade. Um, we would do Christmas programs every year. We would do vacation bible school programs every year. So, I was already working with kids. I was doing activities to keep them excited and interested in music and actually teaching some of the bulk of music even in a church setting. So that, that was another thing.

$\mathrm{I}$ : Ok, what have you done to learn more about teaching elementary music since your college days?

P6: Um, I, of course, when you have the opportunity to go to KMEA, I spend a lot of times going to sessions, especially, that had a lot to do with movement and rhythm. John Jacobson was a presenter a year that I was there so I went to some of his workshops. How do you get the kids moving? How do you get the kids listening and responding to what they hear? So, KMEA is probably the only EXTRA thing I've done.

I: Ok. What do you currently do to improve your teaching and musicianship?

P6: Um, I remain active as a player in my local community band. I'm also heavily involved at my church as part-time director of music where I coach choirs all the way from the seven-year-old and up choirs, youth choirs, to a four-part adult choir. So, that 
doesn't really have that much to do with elementary music. And . . . ask the question again. There was one more thing I wanted to say.

I: What do you currently do to improve your teaching and musicianship?

P6: Oh, another thing that I do is with the teacher program that I am a part of with my first year, there's a lot of looking at lesson plans and doing analysis of what went well, didn't go well, what can I do to better next time? So you know, there's a lot of journaling and self-reflection on lesson quality.

I: Ok, do you have a mentor, peer, or support group that you turn to for advice about teaching elementary music?

P6: I do. I was in a unique position that the teacher who was the music teacher before me is now the curriculum director in the building. Um, so she is very familiar with both schools, what the students have learned so far and what their history is. Um, I'm getting distracted again. Re-ask the question. [laughter]

I: Do you have a mentor, peer, or support group that you turn to for advice about teaching elementary music?

P6: Yes! And I have one other new teacher and we kind of commiserate every once in a while.

I: So it's not another music teacher, it's another classroom teacher?

P6: She was, yes, I would commiserate with another first year teacher about all the paperwork we had to do. The former music teacher is acting as my official mentor for the mentoring program I was in. I am was part of a first-year mentoring program.

I: Ok, are there any musical experiences you had as a child that you are now sharing with your students?

P6: Ooo ... that's a good one! [laughter] Um ... I think singing alone and with others, a varied repertoire of music is the only thing is probably the only experience that I share. That's probably the only thing in common from the last twenty years.

I: [laughter] Nice quote of the national standards!

P6: I thought you'd like that one!

I: Ok, how does your current elementary music classroom compare to your experiences when you were a student in elementary music class?

P6: I am a MUCH better music teacher than my music teacher was. And I don't say that to brag, I just remember that all we did in elementary was-in the spring, we would get 
ready for the spring musical and in the fall, we would get ready for the winter musical. And they were always like these big musical collage things. We never learned about notes and rhythms. All that I learned in band.

I: Ok, was everyone in the school required to participate in the musicals there?

P6: Yes, everyone in the school was.

I: Did you mainly sing, or have instrument parts, or act out like a play?

P6: It was singing with, um, narration.

I: No instruments.

P6: Nope, no instruments. We actually didn't have band in elementary school. We had to wait until middle school. And no drums, no nothing.

I: Do you think that experience helped prepare you for your job where you have to do the Christmas program for the whole school?

P6: No, because when I went back ... well, no. 'Cause when I went back and visited my elementary music teacher as I was going through my teacher preparation program at UofL, I found that I already had a better grasp at teaching than he did. And that's a hard thing to realize, because you think your teachers are just the most awesome thing in the world when you're a kid.

$\mathrm{I}: \mathrm{Ok}$, is there anything else you would like to share regarding your preference for elementary music that we have not yet discussed?

P6: Um, not that I can think of. 


\section{Transcript of Interview with Participant \#7}

Investigator: How long have you been a teacher?

Participant \#7: Five years.

I: And where did you get your teacher training and official degree certification?

P7: Morehead State University.

I: Ok, did you get your bachelors there?

P7: Yes, bachelors of music education. Last summer I finished my masters in educational technology.

I: Ok, at Morehead as well?

P7: Nope, at UofL.

I: What's your major performing area? Vocal or instrumental?

P7: Instrumental.

$\mathrm{I}$ : And your major instrument?

P7: Clarinet.

I: How long have you been at the school you are currently teaching at?

P7: For all five years.

I: All five years. So this is your first teaching position?

P7: Yes.

I: You've never taught at any secondary schools?

P7: Not as a certified teaching position, no. I've taught camps and stuff like that, but not classes.

I: Ok, what grades and ensembles do you currently teach?

P7: Kindergarten through fifth grade.

I: You don't have any band, or choir, or Orff ensembles? 
P7: Um, I have a choir and I do ... um, STOMP as an extracurricular.

I: Ok. Do you teach anything other than music like art, dance, or drama?

P7: Um, I incorporate dance into my curriculum. That's part of my ... expectations on the arts team.

I: Ok. What attracted you to your current position?

P7: At my school or at the elementary level?

I: Your current job at that school.

P7: Um, it was the one that was available. I knew that I wanted to be at

County because they support the arts and I wouldn't have to worry about losing my job. And I happened to be working in a summer program/after-school care at my old school and volunteering with my old music teacher. I would go in and teach lessons with her and hang out in the classroom and stuff like that. It just so happened that this building was being built and I was student teaching at the time. The principal of my school now came out to interview and find teachers and speak with them. They called me and I was very excited and very interested. It was a brand new school so I got to start the program. I got to kind of set the expectations of what a music program was going to be like, and what materials I was going to use, and things of that sort. So, that was a big thing for me. And, it was a job in County.

I: Ok, what do you like about teaching elementary age children?

P7: Um, I like that ... um, it's a chance to be able to expose the kids to something that they may not always have access to. And to push them a little bit in different directions to kind of figure out their interests before they get pigeon-holed in middle school and high school and things of that sort whether they want sports or music, or into different types of music, whether it be choral or instrumental and those kinds of things. And I like working with beginning kids, you know, not ... not be critiquing to the point of perfection but getting them started and showing them how we can get started and everything else like that in the beginning levels.

I: Ok, do you have a preference for a particular age or grade level?

P7: Um, right now I typically ... um, enjoy and feel like a do a little bit better job with my intermediate level kids - third, fourth, and fifth grade. Um, and I think part of that comes with the curriculum, feeling like I HAVE to be pushing information to those kids at a younger level instead of just letting them experience. And having plans that allow them to experiment and explore and not identify as much. But if I was able to explore a little bit more, then I might enjoy my younger kids. Right now I feel like I struggle with them a little bit more, just to get information to them. 
I: Ok, do you feel that you are successful as an elementary music teacher?

P7: I think so. I . . I try to be anyway. I get feedback saying that I am, but, you know, there's always room for improvement. I'm ALWAYS, ALWAYS trying to find different ways of teaching and different ways to do the same information, but in more interesting ways. To ... not get stuck into doing to same things all the time. Yeah, I'm constantly looking for new things and new ways to teach.

I: Ok, what kinds of activities do you most like doing with your children?

P7: Hmm ... I don't know. That one's a hard question! [laughter] There's SO much to do with them! I really like allowing the kids to create stuff, which I don't get to do as often as I would like. Um, I like to be hands-on and teach them how to play something Orff. With my older kids especially, I really enjoy watching my fifth graders have a project at the beginning of the year where they get to completely create their own piece. And watching them go through that process and figuring out what they come up with and then having performances at the end and everything. It's just a really neat process to watch.

I: Are most of these activities things you learned in college or workshops?

P7: Um, a lot of the ideas stem from things I see. But I'm the type of teacher where I don't take something I see and use it exactly. I always mold it to what I want it to be and change it and adjust it based on my kids or my teaching style and what I'm trying to get across to the students. So...

I: So were things you saw at workshops presented or observing other teachers?

P7: Both, yeah. Sometimes ... or sometimes I'll pull things out of books if I see a lesson I'll be, "Well, that's a neat lesson idea with this, but let's expand it or try this." You know, I don't use text books too much. I tend to use the music and then figure out what to do with it.

I: What is you most memorable experience as an elementary music teacher in the past few years?

P7: Oh, I don't know! [laughter] Most memorable ... hmm ... I don't know. I think the things I TRY to remember, the little moments, and a lot of times I can't remember the exact moment. But I like when kids ... those funny moments that happen along the way, you know, where you say something or you do something and the kids say something back to you and it just ... in your mind you just laugh to yourself because ... they either get it or you're like, "WOW! That was totally or completely off base!" Those kinds of things are just priceless.

I: When did you decide you wanted to be an elementary music teacher?

P7: Specifically elementary? Or just going into music? 
I: Specifically elementary.

P7: Um, I think I started more towards the beginning of my junior year in my bachelors degree. I starting taking more of my methods education classes. And um, I just REALLY enjoyed the planning and the younger kids and I knew then that this was the direction I wanted to take. Um, my teaching, that I enjoyed the band side of things, but I was more comfortable teaching the younger kids. So, I tried to mold anything I did, from that point on, toward the elementary level.

I: Do you hope to continue teaching at the elementary level for an extended time?

P7: Yes! Unless I have kids and or something like that where I'm able to stay home, then yeah. I at least plan to continue teaching younger kids, if anything else. I don't mind teaching lessons to older kids, I just don't feel like I'm ... I had a very good mentor and I feel like I need to be able to teach as well as he did at that level with high school and I don't feel that I could do as well as he has. I mean, to try to put myself in that position ... knowing that THIS is what I should be doing and not knowing if I could get there.

I: Ok, think back to your first year teaching. Do you feel like you were prepared to teach elementary music?

P7: Yeah! I actually did. There were always moments and times when I went, "Eww!" Yeah, you know, but I'd always try things and figure it out. The hardest part was the time that it consumes in trying to prepare everything and learning how to deal with the students in the best way for the situation. You're developing your judgment of what's going on in the classroom and multitasking. But, I do. I feel like I was more prepared than some people that go in.

I: Are there things you wish you'd learned before you started that you didn't learn in college?

P7: Um, not necessarily . . because I think I had the tools that they could teach me. The rest of it HAS to come from the experience of working with the kids and just trial and error, figuring out what worked and didn't work in a lesson. But I feel like, the education part, they taught me what I could in classroom styles and observations and parents and things like that but the rest of it just had to be me figuring it out, working it out on my own.

I: What was the most valuable experience during your college training that helped prepare to you to teach elementary general music?

P7: Um, I think my elementary methods class was the biggest part of it. I had a VERY, VERY good professor who taught that class at the time and she was lovely and very much into the kids and that really kind of shown through. And that made you want to be the same way and be creative and have fun with it. I started in that classroom doing more 
of my Orff kind of things and being able to go to conferences and things like that to develop and see other teachers demonstrate their skills. So that was the biggest help for me.

I: Ok, do you think there were any other experiences outside of college that helped prepare you to teach elementary music?

P7: Yeah. Um, my neighbor, who was my preschool teacher, she always had me come over. I would work with the kids over there and help teach over there and do music lessons there. I also did after-school care with elementary kids which really helped with just being around kids and understanding how to handle groups of kids, even though it was smaller groups. And then, you know, finally, volunteering with music teacher was probably one of the best things I could have done. Because I was able to teach WITH her. I was able to teach in the classroom and get experience that way. And that ULTIMATELY led to me getting a job anyway, that networking through her. And it kept me active while I was searching for a position.

I: So there was a period of time after you graduated that you couldn't find a teaching job?

P7: Well, I graduated in December, so there was nothing that I could've done, um, until the following year. So, it was just a timing thing. I was working afterschool and during the day I substitute taught and volunteered with her and that really helped out a lot.

I: So what age were you when you worked with the preschool students?

P7: Um, I think I did some when I was in high school and then the rest was when I got into college between my breaks or this and that when I was available and home.

I: What have you done to learn more about teaching elementary music since your college days?

P7: I've gone to workshops, um . . . pretty much every year. I've really concentrated on my Orff certification and went to class during several summers actually since I've gotten started. And then I also went back to complete my masters in education with technology to enhance that part, or that aspect of my teaching.

I: Ok, so what do you currently do to improve your teaching and musicianship?

P7: Musicianship? I participate, myself, in a community choir and community band so that I'm still constantly playing and challenging myself. Um, and then for the classroom, again, with the PD. I still go to workshops whenever I can or things during the summer, reading up in different books or journals whenever I get the time. I am constantly talking and conversing with colleagues in the county and things of that sort of what we can do or get different ideas, things of that sort, to help. 
I: Ok, well, the next question was, "Do you have a peer, or mentor, or support group that you turn to for advice?" You say that you talk to the other elementary music teachers in the county?

P7: Yes, yes. We're fortunate to have a smaller district. There's eleven elementary music teachers in my county and we try to get together when we can. This year the district has actually helped that out. When we have PLC's [Professional Learning Communities] on early-release days where we've actually met for a couple hours once a month. That really helps, but you know, any other time, if you have a question or need some ideas for something, we shoot each other emails about different things. We're very good about that support and getting information back quickly.

I: Are there any musical experiences you had as a child that you are now sharing with your students?

P7: Um, I can kind of pretty much constantly. I've been in music since I was four years old. I did piano lessons with my neighbor who was my preschool teacher. Then, because of all that, and even in band, band is more prominent in my mind just because of Orff and things of that sort. But, I'm constantly sharing ideas and things that I learned. You know, trying to help them understand that, even though sometimes they don't feel like they're as good at music, that it takes a while and, you know, it's worth it.

I: Ok. How does your current elementary music classroom compare to your experiences when you were a student in elementary school?

P7: Um, I think there's more information that has to be ... its curriculum based and it's really gotten much bigger these days compared to when I was younger. But, I'm fortunate enough that my elementary music teacher is one of my colleagues. And so, I've pulled a lot of things from her and things of that sort. You know, she still has certain ways of doing things and mine is definitely different. I tend to focus a lot on, or try to focus, on technology and creative ways of getting information to students. Her approach is much more Orff-oriented and mines kind of more of a mixture.

I: Ok, but you do similar activities though?

P7: Uh huh.

I: Is there anything else you would like to share regarding your preference for elementary music that we've not yet discussed?

P7: Um, no, I don't think so. 


\section{Transcript of Interview with Participant \#8}

Investigator: How long have you been a teacher?

Participant \#8: Uh, let's see, this is year four.

I: Ok. Where did you get your teacher training and degree certification?

P8: The University of Louisville.

I: Ok, masters or bachelors?

P8: Bachelors of music education and masters of music education.

I: Ok, and your major performing area—vocal or instrumental?

P8: Instrumental.

I: And your major instrument?

P8: Trumpet.

I: How long have you been at your current school?

P8: Two years.

I: So this isn't your first teaching position?

P8: No, it is not.

I: So, have you ever taught at any secondary schools?

P8: Yes, I have.

I: Was it high school or middle school?

P8: Middle school.

I: Ok, what grades and ensembles do you currently teach?

P8: I currently teach fourth through eighth grade general music and humanities.

I: Do you teach anything other than music? Do you incorporate art, dance, or drama into your elementary classes?

P8: Yes, I do dance and drama more so than art. 
I: Is there a separate art teacher at that school?

P8: Yes, there are three art teachers!

I: Wow! Ok, What attracted you to your current position?

P8: It was very late in the hiring process before I decided to stay in town. So, it was availability. The job was open.

I: Ok, what do you like about teaching elementary age children?

P8: It's a good opportunity to start them on the correct musical path, which is a lot of fun. Um, you know, to influence the way that they read, listen to, and react to music as opposed to relying on somebody else.

I: So, you're not just in charge of the ensembles, you also teach the fourth and fifth grade general music classes?

P8: I do.

I: And there's someone else in charge of $\mathrm{K}$ through 3 ?

P8: Pre-K through 3.

I: Ok, do have a preference for a particular age or grade level?

P8: Not really.

I: Ok, how does the fourth and fifth grade compare to your middle school age children.

P8: Ok, well, they're obviously not as mature. However, they approach things with far fewer preconceptions and generally are a little more eager to jump into things.

I: Ok, do you feel that you are successful as an elementary music teacher?

P8: I do.

I: Could you ever consider yourself to be in a full-time elementary job?

P8: If the job was right, I could consider it.

I: You wouldn't be scared of the younger ones as well?

P8: No.

I: What kinds of activities do you most like doing with your children? 
P8: Um, any kind of activity where we can make or create music. Um, I'm not a huge fan of buying, you know, a book of someone else's arrangements and things for an ensemble or this and that. I'd much rather just get the ball rolling and see what we can create in a given 40 minute class period.

$\mathrm{I}: \mathrm{Ok}$, are these methods things you learned in college or at workshops?

P8: You know, it's a little bit of what I learned in college, a little bit of workshops, and then it's more so just taking little bits of ideas from other people and trying to figure out what makes sense for me.

I: What is your most memorable experience as an elementary music teacher in the past few years?

P8: Any time that they can do some kind of performance of their own work, it's always a lot of fun. So, I've done that twice. Um, we've had little mini-performances of their own pieces. And everybody just loves them. They're a lot of fun.

I: How often do you plan performances throughout a year?

P8: I do two a year-a fall performance and a spring performance.

I: Who all do you get involved in those?

P8: Uh, it is all of the grades.

I: All of the children are expected to participate?

P8: Uh huh.

I: How large is your school?

P8: Total enrollment is about 230 kids. So, not very big.

I: Is that all in all, K-8.

P8: Yeah, that's total.

I: Does it go through twelfth grade?

P8: No, just through eight. It's about twelve kids a class.

I: Twelve kids in each grade level?

P8: No, well, each grade level has two classes, so about twelve kids a class and less than 25 per grade level. 
I: Wow. When did you decide you wanted to teach elementary music?

P8: About half-way through the year when I was actually doing it. I kinda ... I went in a little bit kicking and screaming just because it was what was available. And then I started to figure as the year went on, there is a lot of cool things that you can do.

I: So did you not enjoy your student teaching in an elementary school?

P8: No, I had a blast student teaching in elementary school! I just didn't think I'd end up doing it.

I: Do you hope to continue student teaching at the elementary level for an extended time?

P8: I do! I'm done with marching band!

I: Think back to your first year teaching, I guess teaching in elementary. Did you feel like you were prepared to teach elementary?

P8: I did. I felt like I was ready to go. You know, there's nothing to be afraid of. I think that's what more people could stand to learn than anything. Just jump in and try something. If it doesn't work, do something different the next day. So, I wasn't afraid.

I: Are there things you wish you'd learned in college before you started in elementary as a music teacher?

P8: Are there things I wish I'd learned?

I: Yeah.

P8: Of course. But, how many credit hours can we make that degree?

I: Right.

P8: I guess, if I could've changed something, I really would like to see . . and it's better now than it was when we were there. Um, but I would have like to have seen more required classroom time. You know, that's where you learn everything. You learn more in student teaching; it feels like, than in all the other years combined. So, I just think more classroom time built in. You know, I think that would have been the only way, realistically, that more preparation could have been done at the same time.

I: Ok. What was the most valuable experience during your college training that did help prepare you to teach elementary music?

P8: It was student teaching . . . to be put with a GOOD mentor.

I: Ok, who was your mentor? 
P8:

I: Yeah, he's probably a good match for you. You both have similar personalities.

P8: Well, I had him and of the same ended up with had him. You know, we all ... everyone that was kind

I: Do you think there were other experiences outside of college that have helped prepare you to teach elementary music?

P8: Um, well, yeah. I mean, any interaction with kids is helpful in preparing. Whether it's ... you know, just volunteering and helping out with younger kids. Like when I helped out with an audition day. Any experience working with someone younger than you helps prepare you to be a teacher.

I: Ok, what have you done to learn more about teaching elementary music since your college days?

P8: I've tried to go to more clinics and sessions just to stay current on ideas and to stay fresh to see what, you know, leader thinkers are thinking so I don't have to try and reinvent the wheel. Um, the biggest and best experience is Orff, um, Schulwerk every year. I've got to go to it the last two years and that's just been a blast. There's a lot of great ideas stemming from that. Hopefully I can get certified.

I: You've attended the Orff conference or the levels courses?

P8: Oh, no, the conference! I haven't done my levels ... yet.

I: But you went to AOSA twice?

P8: Uh huh.

$\mathrm{I}: \mathrm{Ok}$, what do you currently do to improve your teaching and musicianship?

P8: As far as musicianship, I still actively practice. I still perform every chance that I can. Uh, and that's the better musician that I can be. Um, the better job I can do with my kids. In addition, I'm also trying to pick up a couple new instruments every year. You know, not necessarily to be that great at them, but just to function on them. And as far as practicing teaching, the biggest thing is just, you know, take a little honest reflection time after you do something and figuring out what really did work and what really didn't work. That's the biggest thing I can do on a daily basis to impact my teaching. To think-what actually really made this successful or what didn't? And keep what works and try to get rid of or improve the things that didn't.

I: Ok, do you have a mentor, peer, or support group that you turn to for advice about teaching elementary music? 
P8: There's not one that's really set in stone or assigned to me, because I'm in a private school and they're a little bit less frigged as far as that stuff goes. But, pretty much all of us that came through school at the same time, I know that I could call any of them and . . . um, throw out ideas back and forth. That's the biggest one ... or just go out some time and vent. You know, if things aren't really going so well. Having another music teacher in the building is helpful too. Just to talk around ideas. So, there's not really one assigned to me, but I do feel like there's a pretty good support structure around.

I: Are there any musical experiences you had as a child that you are now sharing with your students?

P8: My own child musical experience was pretty weak. Actually, the only thing I can remember about general music class is that we used to watch David Bowie videos.

I: [laughter]

P8: I mean, REALLY! That's what we did!

I: So you watched a lot of videos?

P8: Yeah, we just watched David Bowie videos nonstop! Uh, so I know a lot about David Bowie, which is not something that I particularly want to share. [laughter] Um, I try to give them the things that I think would have been more helpful to me. So, I didn't have to feel like I was playing catch-up. And then, um, you know, also, with the thesis I did a couple of years ago where I was trying to figure out what experiences students thought was the most beneficial to them becoming a music major, I try to throw some of that in as well. You know, I did all the work and the research on that. Some of those exercises and the small experiences that I can give them have been some of the more successful things, especially as they get a little older.

I: Ok, so how does your current elementary music classroom compare to your experiences when you were a student in elementary school?

P8: I would like to think its MUCH better ... because there's just so little I remember from my own background. You know, I couldn't even tell you who my old music teacher's name was ... to be honest. Um, so, I'm hopeful that I can create some pretty vivid memories and experiences. And I try to just do ... something that's meaningful every day. I don't think I had that because I can't remember it ... at all. So, hopefully it's much better than what I had.

I: Ok, is there anything else you would like to share regarding your preference for elementary music that we have not yet discussed?

P8: I would just like ... and I don't know who would necessarily end up reading this ... I just really would like to see the younger music education generation, the trainees, the college students, give this outlook a sincere ... No, not outlook. Uh, to give this career 
path a serious chance, to really look at it. Because, for me, this was not something I was really planning on. And I don't think it was necessarily was for you either, initially. And um ... it ends up being the BEST option. I would just like to see a lot more of the students be a little bit more comfortable with saying, "It's ok to break away from the ensemble route," a little bit. And just see how creative you can be in a given day. And I bet a lot of them would enjoy it.

I: Do you think that they're not as comfortable because elementary music is so far different from what we experiences as children in elementary music? I mean, it's just come a long way.

P8: I think that's part of it. But I think also, as far as the comfort level, if you're teaching a middle school band, and I know because I've done this, um, you can hide behind that method book. You know, on Monday we can do lines 1, 2, and 3, on Tuesday we can do 3,4 , and 5 , and so on. And there it is. Once September rolls around, we can start prepping for the concert, I mean, you know. It can get in to being fairly predictable . . . and safe. I just think if they ... if they can just get over the fact that there's going to be a little uncomfortability for a couple months, what you can end up with is . . honestly, I never though I'd say this but ... a much more satisfying end product BECAUSE I'm not trying to get specific notes in a specific order or rarely, if ever. It's "how can you give me a creative response to this?" and in the end I think that's more useful.

I: Well, let me ask you another question real quick. At both, when you had the middle school separately and now you're still teaching middle school students, you had to teach general music classes as well, right? Besides ensembles?

P8: I had to teach one eighth grade class at my old job. It was general music.

I: Since you've been responsible for elementary school, do you think your approach to teaching those general music classes has changed any?

P8: Absolutely! I mean, at the previous job, it was ... I'm ashamed to admit this, but I'll do it anyway, it was a throw-away class. You know, it was a class that they made teach so that I could be full-time there ... and that's really how I approached it. I didn't really care to see what kinds of things I could do. It was just, "here we go, let's get done with this." Where as now, there's a lot of things that COULD be done and SHOULD be done and I actively seek those out, where as before I never did. 


\section{CURRICULUM VITAE}

NAME: $\quad$ Rebecca llene Dennis

ADDRESS: 8016 Apple Valley Drive

Louisville, KY 40228

rebecca.dennis@bullitt.kyschools.us

DOB: $\quad$ Hardinsburg, Kentucky - August 5, 1983

EDUCATION: $\quad$ University of Louisville, Louisville, KY

MME, expected date of completion December 2010

University of Louisville, Louisville, KY

BME, with honors, Spring 2005

Grayson County High School, Leitchfield, KY

Diploma, Spring 2001

TEACHING

EXPERIENCE: $\quad$ Cedar Grove Elementary School, Shepherdsville, KY

Fall 2005-present

Elementary General Music Teacher

Responsibilities included:

Fifth Grade Beginning Band, 2005-2007

Fourth and Fifth Grade Choir, 2005-present

Fourth and Fifth Grade Orff Ensemble, 2007-present

Arts and Humanities CATS test preparation

Supplemental dance instruction

Minors Lane Elementary, Louisville, KY

Student Teacher

Spring 2005

Youth Performing Arts School, Louisville, KY

Student Teacher Spring 2005 
Level III Certification, Orff-Schulwerk

University of Kentucky; Lexington, KY

Instructors: Jay Broeker, Cindy Hall, and Brian Burnett

Summer 2008

Advanced Orff Course: Curriculum Development

University of Kentucky; Lexington, KY

Instructor: Jay Broeker

Summer 2007

Level II Certification, Orff Schulwerk

University of Kentucky; Lexington, KY

Instructors: Cindy Hall, Brian Crisp, and Brian Burnett

Summer 2006

Level I Certification, Orff Schulwerk

University of Kentucky; Lexington, KY

Instructors: Brian Crisp, Cindy Hall, and Brian Burnett

PROFESSIONAL

AFFILIATIONS: Kentucky Music Educators Association (2001-2010)

Kentucky Orff-Schulwerk Association (2005-2010)

Delta Omicron International Music Fraternity (2001-2005)

International Trumpet Guild (2001-2005)

REFERENCES: $\quad$ Robert Amchin, PhD

Professor of Music Education

University of Louisville

Louisville, $\mathrm{KY}$

Phone: 502-852-0536

E-mail: robamchin@insightbb.com

Alicia Franklin

KTIP mentor/Counselor

Cedar Grove Elementary School

1900 Cedar Grove Road

Shepherdsville, KY 40165

Phone: 502-904-0912

E-mail: alicia.franklin@bullitt.kyschools.us 
Curtis Essig

Student Teaching Mentor/Band Director

Youth Performing Arts School

1517 South Second Street

Louisville, KY 40208

Phone: 502-485-8355

E-mail: curtis.essig@jefferson.kyschools.us

Ken Downs

Student Teaching Mentor/Music Teacher

Minors Lane Elementary

8510 Minors Lane

Louisville, KY 40219

Phone: (502) 485-8303

E-mail: ken.downs@jefferson.kyschools.us 